\title{
KOH-Based Modified Solvay Process for Removing Na Ions from High Salinity Reject Brine at High Temperatures
}

\author{
Aya A-H. I. Mourad ${ }^{1,2}$, Ameera F. Mohammad ${ }^{1,3}$, Ali H. Al-Marzouqi ${ }^{1, *(\mathbb{D}, \text { Muftah H. El-Naas }}{ }^{4, *(\mathbb{D} \text {, }}$ \\ Mohamed H. Al-Marzouqi ${ }^{1}$ and Mohammednoor Altarawneh ${ }^{1}$ \\ 1 College of Engineering, UAE University, Al Ain 15551, United Arab Emirates; \\ 200834607@uaeu.ac.ae (A.A-H.I.M.); a.fares@uaeu.ac.ae (A.F.M.); mhhassan@uaeu.ac.ae (M.H.A.-M.); \\ mn.altarawneh@uaeu.ac.ae (M.A.) \\ 2 Academic Support Department, Abu Dhabi Polytechnic, Institute of Applied Technology, \\ Abu Dhabi 111499, United Arab Emirates \\ 3 Chemical Engineering Department, KU Leuven, 3001 Leuven, Belgium \\ 4 Gas Processing Center, College of Engineering, Qatar University, Doha 2713, Qatar \\ * Correspondence: hassana@uaeu.ac.ae (A.H.A.-M.); muftah@qu.edu.qa (M.H.E.-N.); \\ Tel.: +971-3-713-4470 (A.H.A.-M.); +974-4403-7695 (M.H.E.-N.)
}

check for updates

Citation: Mourad, A.A-H.I.; Mohammad, A.F.; Al-Marzouqi, A.H.; El-Naas, M.H.; Al-Marzouqi, M.H.;

Altarawneh, M. KOH-Based Modified Solvay Process for Removing Na Ions from High Salinity Reject Brine at High Temperatures. Sustainability 2021, 13, 10200. https://doi.org/ $10.3390 /$ su131810200

Academic Editor: Agostina Chiavola

Received: 19 July 2021

Accepted: 7 September 2021

Published: 13 September 2021

Publisher's Note: MDPI stays neutral with regard to jurisdictional claims in published maps and institutional affiliations.

Copyright: (C) 2021 by the authors. Licensee MDPI, Basel, Switzerland. This article is an open access article distributed under the terms and conditions of the Creative Commons Attribution (CC BY) license (https:// creativecommons.org/licenses/by/ $4.0 /)$.

\begin{abstract}
The traditional Solvay process and other modifications that are based on different types of alkaline material and waste promise to be effective in the reduction of reject brine salinity and the capture of $\mathrm{CO}_{2}$. These processes, however, require low temperatures $\left(10-20^{\circ} \mathrm{C}\right)$ to increase the solubility of $\mathrm{CO}_{2}$ and enhance the precipitation of metallic salts, while reject brine is usually discharged from desalination plants at relatively high temperatures $\left(40-55^{\circ} \mathrm{C}\right)$. A modified Solvay process based on potassium hydroxide $(\mathrm{KOH})$ has emerged as a promising technique for simultaneously capturing carbon dioxide $\left(\mathrm{CO}_{2}\right)$ and reducing ions from reject brine in a combined reaction. In this study, the ability of the $\mathrm{KOH}$-based Solvay process to reduce brine salinity at relatively high temperatures was investigated. The impact of different operating conditions, including pressure, $\mathrm{KOH}$ concentration, temperature, and $\mathrm{CO}_{2}$ gas flowrate, on $\mathrm{CO}_{2}$ uptake and ion removal was investigated and optimized. The optimization was performed using the response surface methodology based on a central composite design. $\mathrm{A} \mathrm{CO}_{2}$ uptake of $0.50 \mathrm{~g} \mathrm{CO}_{2} / \mathrm{g} \mathrm{KOH}$ and maximum removal rates of sodium $\left(\mathrm{Na}^{+}\right)$, chloride $\left(\mathrm{Cl}^{-}\right)$, calcium $\left(\mathrm{Ca}^{2+}\right)$, and magnesium $\left(\mathrm{Mg}^{2+}\right)$ of $45.6 \%, 29.8 \%, 100 \%$, and $91.2 \%$, respectively, were obtained at a gauge pressure, gas flowrate, and $\mathrm{KOH}$ concentration of 2 bar, $776 \mathrm{~mL} / \mathrm{min}$, and $30 \mathrm{~g} / \mathrm{L}$, respectively, and at high temperature of $50^{\circ} \mathrm{C}$. These results confirm the effectiveness of the process in salinity reduction at a relatively high temperature that is near the actual reject brine temperature without prior cooling. The structural and chemical characteristics of the produced solids were investigated, confirming the presence of valuable products such as sodium bicarbonate $\left(\mathrm{NaHCO}_{3}\right)$, potassium bicarbonate $\left(\mathrm{KHCO}_{3}\right)$ and potassium chloride $(\mathrm{KCl})$.
\end{abstract}

Keywords: reject brine; $\mathrm{CO}_{2}$ capture; optimization; RSM; modified Solvay process; potassium hydroxide; hot pot potassium carbonate process

\section{Introduction}

The Solvay process is an effective approach for treating carbon dioxide $\left(\mathrm{CO}_{2}\right)$ produced from fossil fuel power plants and brine rejected from desalination industries in a single reaction [1]. Many factors affect the performance of the combined process, such as the reaction temperature, alkaline type, and solution $\mathrm{pH}$. Among these variables, temperature has the greatest impact on the process because it controls the solubility of $\mathrm{CO}_{2}$ and metal ions in the brine [1]. Generally, high temperatures have a negative effect on the solubility of $\mathrm{CO}_{2}$ and decrease the precipitation of metal ions such as sodium $\left(\mathrm{Na}^{+}\right)$ions, which are present in the brine at high concentrations compared with other ions such as calcium $\left(\mathrm{Ca}^{2+}\right)$, magnesium $\left(\mathrm{Mg}^{2+}\right)$, and chloride $\left(\mathrm{Cl}^{-}\right)$. The main objective of the traditional Solvay 
process is to produce insoluble sodium bicarbonate $\left(\mathrm{NaHCO}_{3}\right)$ via the reaction of the sodium chloride with $\mathrm{CO}_{2}$ in the presence of ammonia $\left(\mathrm{NH}_{3}\right)$, according to Equation (1) [2].

$$
\mathrm{NaCl}+\mathrm{NH}_{3}+\mathrm{CO}_{2}+\mathrm{H}_{2} \mathrm{O} \leftrightarrow \mathrm{NaHCO}_{3}+\mathrm{NH}_{4} \mathrm{Cl}\left(\Delta \mathrm{G}_{20 \mathrm{C}}=-59.7 \mathrm{~kJ} / \mathrm{kmol}\right)
$$

Mohammad et al. [2] investigated the parametric sensitivity of the traditional Solvay process to optimize the conditions of the entire process. The response surface methodology (RSM) using Minitab 19.0 software was employed to optimize the responses under different ranges of temperature $\left(13.2-46.8^{\circ} \mathrm{C}\right), \mathrm{CO}_{2}$ gas flowrate $(0.659-2.341 \mathrm{~L} / \mathrm{min})$, and $\mathrm{NH}_{3}$ to-sodium chloride $(\mathrm{NaCl})$ molar ratio (1.7-3.3). All experiments were performed at atmospheric pressure. A maximum $\mathrm{CO}_{2}$ capture efficiency of $86 \%$ and $\mathrm{Na}^{+}$removal efficiency of $33 \%$ were achieved at a temperature, gas flowrate and $\mathrm{NH}_{3}: \mathrm{NaCl}_{\text {molar ratio }}$ of $19^{\circ} \mathrm{C}, 1.54 \mathrm{~L} / \mathrm{min}$, and 3.3, respectively. Moreover, increasing the temperature from $13.2{ }^{\circ} \mathrm{C}$ to $46.8^{\circ} \mathrm{C}$ caused a remarkable decrease in the $\mathrm{CO}_{2}$ and $\mathrm{Na}^{+}$removal efficiency. Palitsakun et al. [3] investigated the impact of temperature and $\mathrm{CO}_{2}$ flowrate on the performance of the traditional Solvay process based on $\mathrm{NH}_{3}$, obtaining the maximum $\mathrm{NaHCO}_{3}$ amount of 20.67 wt. \% at a temperature, $\mathrm{CO}_{2}$ flowrate, and $\mathrm{NaCl}$ concentration of $20{ }^{\circ} \mathrm{C}, 0.1 \mathrm{~L} / \mathrm{min}$, and $3 \mathrm{M}$, respectively, using a $43 \mathrm{wt}$ \% $\mathrm{NH}_{3}$ solution. Moreover, a significant reduction in the $\mathrm{CO}_{2}$ capture efficiency from $\sim 93 \%$ to $80 \%$ was observed when the temperature was increased from $20^{\circ} \mathrm{C}$ to $38^{\circ} \mathrm{C}$.

Although $\mathrm{NH}_{3}$ was used as a catalyst to enhance the reaction rate by increasing the $\mathrm{pH}$, $\mathrm{NH}_{3}$ is environmentally hazardous and its recovery is costly [2]. In this context, a calcium oxide (CaO)-based modified Solvay process (Equation (2)) was studied as an alternative by El-Naas et al. $[4,5]$. This process not only avoids the harmful impacts of the conventional Solvay process, but also achieves better performance in terms of $\mathrm{CO}_{2}$ capture, $\mathrm{Na}^{+}$removal, and energy consumption. Furthermore, $\mathrm{CaO}$ could maintain a high $\mathrm{pH}$ value of 11.8.

$$
2 \mathrm{NaCl}+2 \mathrm{CO}_{2}+\mathrm{Ca}(\mathrm{OH})_{2} \leftrightarrow 2 \mathrm{NaHCO}_{3}+\mathrm{CaCl}_{2}\left(\Delta \mathrm{G}_{20 \mathrm{C}}=-56.0 \mathrm{~kJ} / \mathrm{kmol}\right)
$$

These authors employed RSM to optimize the entire process, achieving a maximum $\mathrm{CO}_{2}$ uptake of $0.92 \mathrm{~g} \mathrm{CO}_{2} / \mathrm{g} \mathrm{CaO}$ and $\mathrm{Na}^{+}$removal of $35 \%$ under optimum conditions of $20^{\circ} \mathrm{C}$ temperature, atmospheric pressure, $1 \mathrm{~L} / \mathrm{min} \mathrm{CO}_{2}$ flowrate, and $20 \mathrm{~g} / \mathrm{L} \mathrm{CaO}$ (more than the solubility limit). Increasing the temperature from $20{ }^{\circ} \mathrm{C}$ to $50{ }^{\circ} \mathrm{C}$ led to a significant reduction in $\mathrm{Na}^{+}$removal from $35 \%$ to nearly $5 \%$, resulting in less precipitation of $\mathrm{NaHCO}_{3}$ [4].

Dindi et al. [6] examined the effectiveness of mixed metal oxides on $\mathrm{CO}_{2}$ capture and reject brine management in a combined process. $\mathrm{A} \mathrm{CO}_{2}$ uptake of $0.082 \mathrm{~g} \mathrm{CO} / \mathrm{g}$ carbonated solution and a $\mathrm{Na}^{+}$reduction of $20 \%$ in reject brine were achieved at $25{ }^{\circ} \mathrm{C}$ and 1 bar. Shim et al. [7] investigated the $\mathrm{CO}_{2}$ capture efficiency at ambient temperature by reacting it with a sodium hydroxide $(\mathrm{NaOH})$ solution produced from $\mathrm{NaCl}$ electrolysis. Up to $95 \%$ of $\mathrm{CO}_{2}$ capture and $97 \% \mathrm{NaHCO}_{3}$ production were obtained. The entire process was conducted at ambient temperature and pressure. Recently, Ibrahim et al. [8] examined the use of steel-making bag house dust (BHD) as a potential source of $\mathrm{CaO}$ in the modified Solvay process. A maximum $\mathrm{CO}_{2}$ uptake of $(1 \pm 0.04) \mathrm{g} \mathrm{CO}_{2} / \mathrm{g} \mathrm{BHD}$ was achieved at ambient temperature and a pressure of 5 bar. Moreover, the precipitation of $\mathrm{NaHCO}_{3}$ occurred at a low temperature of $15^{\circ} \mathrm{C}$.

Recently, Mourad et al. [9] investigated the effectiveness of potassium hydroxide $(\mathrm{KOH})$ in the Solvay process. $\mathrm{KOH}$ was selected owing to its potential in directly capturing $\mathrm{CO}_{2}$ from ambient air [10-15]. The overall reaction of the modified Solvay process based on $\mathrm{KOH}$ as the alkaline material can be described using Equation (3) [9].

$$
\mathrm{NaCl}+\mathrm{CO}_{2}+\mathrm{KOH} \leftrightarrow \mathrm{NaHCO}_{3}+\mathrm{KCl}\left(\Delta \mathrm{G}_{20 \mathrm{C}}=-130.6 \mathrm{~kJ} / \mathrm{kmol}\right)
$$

This process was studied under the same optimized conditions of temperature, pressure, and gas flowrate previously reported by El-Naas et al. [4], where CaO was used as 
the alkaline material instead of $\mathrm{NH}_{3}$. The initial results revealed that $\mathrm{KOH}$ is a promising alkaline material, which can significantly accelerate $\mathrm{CO}_{2}$ capture efficiency owing to its high solubility in treated brine and its ability to maintain a high $\mathrm{pH}$ value $(\sim 13.6)$. The $\mathrm{CO}_{2}$ uptake and $\mathrm{Na}^{+}$removal reached up to $0.31 \mathrm{~g} \mathrm{CO} 2 / \mathrm{g} \mathrm{KOH}$ and $29 \%$, respectively, at a temperature, pressure, gas flowrate, and $\mathrm{KOH}$ concentration of $20{ }^{\circ} \mathrm{C}, 1 \mathrm{~atm}, 1 \mathrm{~L} / \mathrm{min}$, and $70.57 \mathrm{~g} / \mathrm{L}$, respectively. Moreover, the main products formed in this reaction, such as $\mathrm{NaHCO}_{3}$ and potassium chloride $(\mathrm{KCl})$, have various industrial applications [9].

Based on the above literature review, temperature has been found to be a vital parameter that significantly affects the combined process in terms of metal solubility and $\mathrm{CO}_{2}$ uptake. Notably, low temperature conditions are generally preferred to achieve high $\mathrm{CO}_{2}$ capture and ion removal from reject brine. However, brine is commonly discharged from desalination plants at relatively high temperatures of $40-55^{\circ} \mathrm{C}$ [16]. To the best of the authors' knowledge, no previous works have achieved the optimization of the $\mathrm{KOH}$ based Solvay process to achieve high $\mathrm{CO}_{2}$ capture and ion removal at high temperatures. Therefore, in this study, the optimal operating conditions (gas flowrate, pressure, and $\mathrm{KOH}$ concentration) were experimentally investigated to achieve the maximum ion removal and $\mathrm{CO}_{2}$ uptake at relatively high temperatures $\left(40-60^{\circ} \mathrm{C}\right)$. Moreover, the structural and chemical characteristics of the precipitated solids were examined using X-ray diffraction (XRD), scanning electron microscopy (SEM), and Fourier transform infrared (FTIR) spectroscopy.

\section{Materials and Methods}

\subsection{Materials}

A gas mixture comprising $10 \% \mathrm{CO}_{2}$ and $90 \%$ air was obtained from Abu Dhabi Oxygen Company, UAE. KOH with a particle size of $5-7 \mathrm{~mm}$ and a purity of $85-100 \%$ was acquired from Scientific Progress Medical and Scientific Equipment Company, UAE. The real samples of reject brine were supplied by a multistage flash desalination unit at Abu Dhabi, UAE. The concentrations of $\mathrm{Ca}^{2+}, \mathrm{Na}^{+}$, potassium $\left(\mathrm{K}^{+}\right), \mathrm{Mg}^{2+}$, and $\mathrm{Cl}^{-}$were $933.1 \pm 3.3,23,063.1 \pm 7.4,877.1 \pm 4.1,2675.8 \pm 6.1$, and 48,330 \pm 4.2 ppm, respectively. The $\mathrm{pH}$ of the reject brine was $8.02 \pm 0.01$. The ion concentration in the reject brine was measured using inductively coupled plasma (ICP) spectrometry (Varian 710-ES ICP optical emission spectrometer). $\mathrm{Cl}^{-}$was analyzed using a HACH HQ40D portable multimeter equipped with a $\mathrm{Cl}^{-}$ion-selective electrode (HACH Intellical ${ }^{\mathrm{TM}}$ ISECL181). Additionally, the $\mathrm{pH}$ was measured using a HACH portable $\mathrm{pH}$ meter (Model HQ11D53000000). All measurements were determined by considering the average value of three collected reject brine samples.

\subsection{Experimental Procedure}

In this research, all experiments were conducted in a novel inert-particle spouted bed reactor (IPSBR) developed by El-Nass et al. [17,18]. Figure 1 shows a schematic diagram of the reactor [9]. The inert particles were composed of poly(methyl methacrylate) with an average density and diameter of $1020 \mathrm{~kg} / \mathrm{m}^{3}$ and $0.013 \mathrm{~m}$, respectively. Particles with a volume fraction (volume of particles/volume of reject brine) of $\sim 6 \%$ were used. The internal diameter, height, and total working volume of the reactor were $0.078 \mathrm{~m}, 0.850 \mathrm{~m}$, and $3000 \mathrm{~mL}$ [18-21]. In each experiment, a magnetic stirrer was used to mix a certain amount of $\mathrm{KOH}$ with $1 \mathrm{~L}$ of reject brine. Initially, the IPSBR was filled with the prepared solution and then exposed to a continuous flow of a $\mathrm{CO}_{2}$-air gas mixture via an orifice diameter of $2 \mathrm{~mm}$ from the bottom of the reactor [18]. The gas flowrate was controlled using a mass flow controller. To determine the amount of captured $\mathrm{CO}_{2}$, the outlet gas stream was continuously passed through a $\mathrm{CO}_{2}$ gas analyzer. The pressure was controlled using a backpressure regulator valve at the outlet of the reactor. Each experiment was considered complete when the saturation point was reached, i.e., when the $\mathrm{CO}_{2}$ concentration at the outlet was equal to the inlet value (10 vol. \%). The $\mathrm{pH}$ of the mixture was measured before and after the reaction with $\mathrm{CO}_{2}$ gas. At the end of each experiment, the collected mixture was filtered to separate the liquid from the produced solids using a Büchner setup. The ion 
concentration of the treated brine was measured using ICP spectrometry. The percentage of ion reduction and $\mathrm{CO}_{2}$ uptake was calculated using Equations (4) and (5), respectively [4]. The characteristics of the solids were investigated using different analytical techniques, which is discussed in more detail in Section 4.

$$
\text { Ion reduction }(\%)=\frac{X_{i}-X_{f}}{X_{i}} \times 100,
$$

where $X_{i}$ is the initial ion concentration in the feed brine $(\mathrm{mg} / \mathrm{L})$ and $X_{f}$ is the final ion concentration in the treated brine $(\mathrm{mg} / \mathrm{L})$.

$$
\mathrm{CO}_{2} \text { uptake value }\left(\mathrm{g} \mathrm{CO}_{2} / \mathrm{g} \mathrm{KOH}\right)=\frac{\text { mass of } \mathrm{CO}_{2} \text { reacted }(\mathrm{g})}{\text { mass of } \mathrm{KOH} \text { used }(\mathrm{g})}
$$

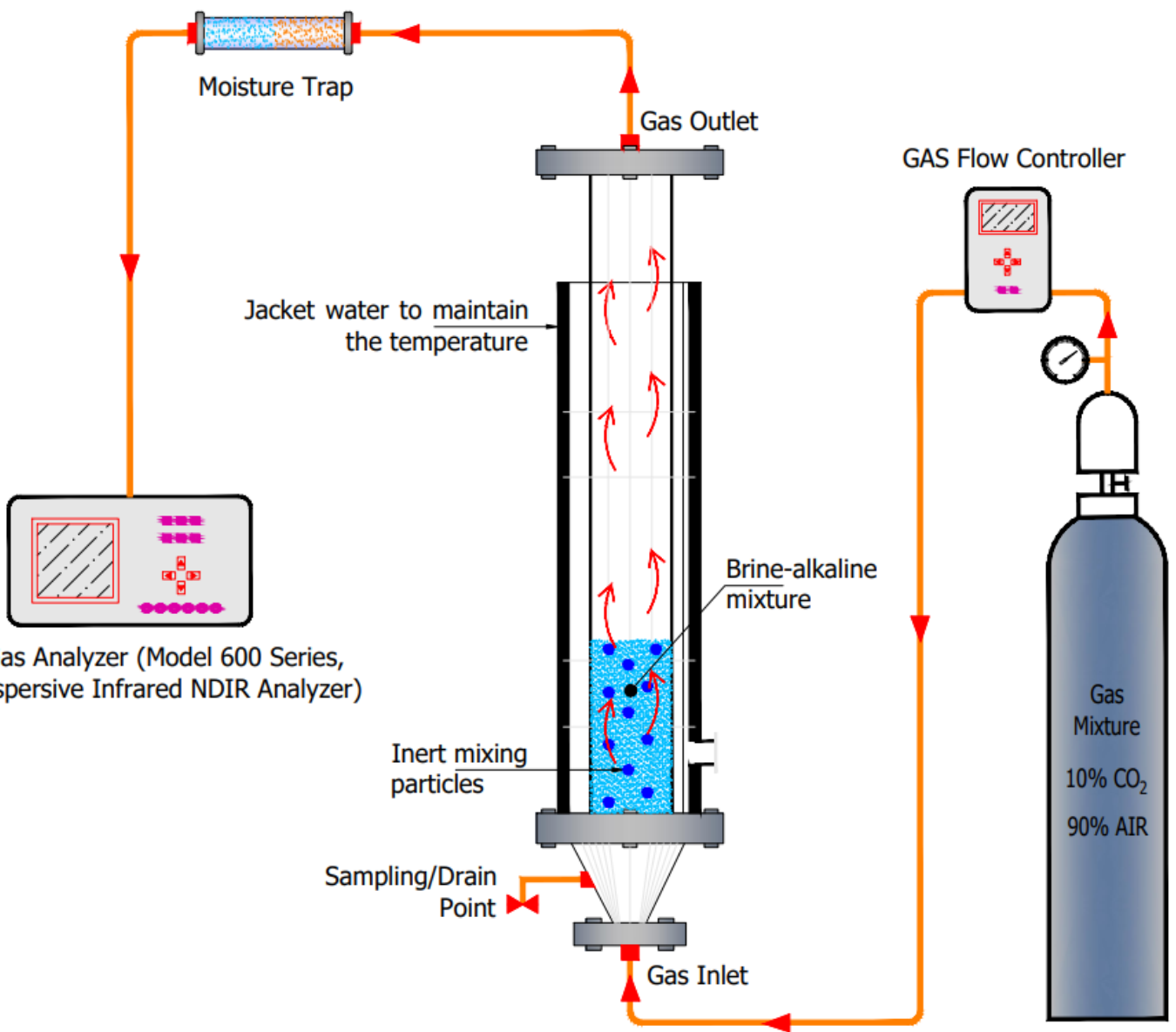

Figure 1. A schematic diagram of the inert-particle spouted bed reactor system (IPSBR) [9].

\subsection{Experimental Design}

To explore the effects of independent variables on the $\mathrm{CO}_{2}$ uptake and ion removal efficiency, a central composite design (CCD) was employed as an optimization tool for RSM using Minitab 19.0 software [20,22]. To determine the optimum conditions, four process-independent variables were considered, namely, temperature, gauge pressure, $\mathrm{KOH}$ concentration, and $\mathrm{CO}_{2}$ flowrate, and their influence on $\mathrm{CO}_{2}$ uptake and ion removal percentage $\left(\mathrm{Ca}^{2+}, \mathrm{Na}^{+}, \mathrm{K}^{+}, \mathrm{Mg}^{2+}\right.$, and $\left.\mathrm{Cl}^{-}\right)$was investigated. Table 1 presents the levels established for the operating parameters. A total of 31 experimental runs was generated in a specific sequence using RSM based on the levels of each factor. After conducting all the experiments, all responses were inserted in the RSM for optimization and predicting the 
ability of the entire process to achieve a good level of $\mathrm{CO}_{2}$ capture and ion removal at a relatively high temperature of $50{ }^{\circ} \mathrm{C}$.

Table 1. Levels of independent factors.

\begin{tabular}{cccccccc}
\hline \multirow{2}{*}{ Independent Variables } & \multirow{2}{*}{ Unit } & Tag & \multicolumn{5}{c}{ Level } \\
\cline { 4 - 8 } & & & $-\boldsymbol{\alpha}$ & $\mathbf{- 1}$ & $\mathbf{0}$ & $\mathbf{+ 1}$ & $+\boldsymbol{\alpha}$ \\
\hline Temperature & ${ }^{\circ} \mathrm{C}$ & $\mathrm{T}$ & 10 & 20 & 30 & 40 & 50 \\
\hline Gauge Pressure & $\mathrm{bar}$ & $\mathrm{P}$ & 1 & 1.5 & 2 & 2.5 & 3 \\
\hline $\mathrm{KOH}$ concentration & $\mathrm{g} / \mathrm{L}$ & $\mathrm{C}$ & 30 & 50 & 70 & 90 & 110 \\
\hline $\mathrm{CO}_{2}$ flowrate & $\mathrm{mL} / \mathrm{min}$ & $\mathrm{F}$ & 400 & 700 & 1000 & 1300 & 1600 \\
\hline
\end{tabular}

\section{Results and Discussion}

In the following sections, the investigation of the impact of the operating parameters and their interactions on $\mathrm{CO}_{2}$ uptake and ion removal is described. The relation between the independent variables, i.e., temperature, pressure, flowrate, and $\mathrm{KOH}$ concentration, and responses can be represented using three-dimensional (3D) plots (Figures 2-5).

\subsection{Impact of Independent Factors on $\mathrm{CO}_{2}$ Uptake}

Figure 2 a reveals a significant linear relation between pressure and $\mathrm{CO}_{2}$ uptake. The $\mathrm{CO}_{2}$ uptake of nearly $0.76 \mathrm{~g} \mathrm{CO}_{2} / \mathrm{g} \mathrm{KOH}$ was achieved at maximum gauge pressure of 3 bar, followed by a decrease to almost half the maximum value, around $0.38 \mathrm{~g} \mathrm{CO}_{2} / \mathrm{g} \mathrm{KOH}$, at a gauge pressure value of 1.5 bar over the whole range of concentration. These experiments were performed at a constant temperature and gas flowrate of $30{ }^{\circ} \mathrm{C}$ and $1000 \mathrm{~mL} / \mathrm{min}$, respectively. This considerable effect of the pressure on $\mathrm{CO}_{2}$ uptake was expected; as the pressure increased, more $\mathrm{CO}_{2}$ was solubilized, shifting the reaction (Equation (3)) toward the product side. The 3D plot shown in Figure $2 \mathrm{~b}$ reveals that the maximum $\mathrm{CO}_{2}$ uptake was obtained at a maximum gas flowrate of $1600 \mathrm{~mL} / \mathrm{min}$ and a low temperature of $10{ }^{\circ} \mathrm{C}$, owing to the high solubility of $\mathrm{CO}_{2}$ gas at low temperatures $[1,4,8]$. Furthermore, $\mathrm{CO}_{2}$ uptake still reached a value of up to $0.53 \mathrm{~g} \mathrm{CO}_{2} / \mathrm{g} \mathrm{KOH}$ at a temperature of $30{ }^{\circ} \mathrm{C}$ and a low gas flowrate of nearly $400 \mathrm{~mL} / \mathrm{min}$. This observation confirms the effect of gas flowrate on $\mathrm{CO}_{2}$ uptake, where a low gas flowrate resulted in a high residence time and hence high $\mathrm{CO}_{2}$ capture $[4,8]$. This result reflects the novelty of the IPSBR [18-20], which can still operate under high feed-gas flowrate and achieve high $\mathrm{CO}_{2}$ uptake under certain conditions. Figure 2c demonstrates the impact of the interaction between temperature and pressure on the $\mathrm{CO}_{2}$ uptake. As a general conclusion, the uptake increases with the pressure at a constant temperature. This is for the studied ranges of temperature $\left(10-50^{\circ} \mathrm{C}\right)$ and gauge pressure (1-3 bar). These results were achieved under a constant gas flowrate of $1000 \mathrm{~mL} / \mathrm{min}$ and a $\mathrm{KOH}$ concentration of $70 \mathrm{~g} / \mathrm{L}$.

\subsection{Impact of Independent Factors on $\mathrm{Na}^{+}$and $\mathrm{Cl}^{-}$Removal from Reject Brine}

Figure $3 a, b$ present the impact of independent parameters on $\mathrm{Na}^{+}$reduction. Figure $3 a$ shows good $\mathrm{Na}^{+}$removal over the range of temperatures. These data were measured under a constant gauge pressure of 2 bar and a $\mathrm{KOH}$ concentration of $70 \mathrm{~g} / \mathrm{L}$. Further, Figure $3 \mathrm{~b}$ depicts the effect of the interaction between temperature and $\mathrm{KOH}$ concentration on the response, which was evaluated under a constant gauge pressure of 2 bar and a gas flowrate of $1000 \mathrm{~mL} / \mathrm{min}$. The maximum $\mathrm{Na}^{+}$removal efficiency was achieved at a low temperature and a high concentration of $110 \mathrm{~g} / \mathrm{L}$, which was beyond the stoichiometric value $(70.57 \mathrm{~g} / \mathrm{L})$. Moreover, a good $\mathrm{Na}^{+}$removal efficiency can still be achieved at high temperatures and low $\mathrm{KOH}$ concentrations $(30 \mathrm{~g} / \mathrm{L})$. 


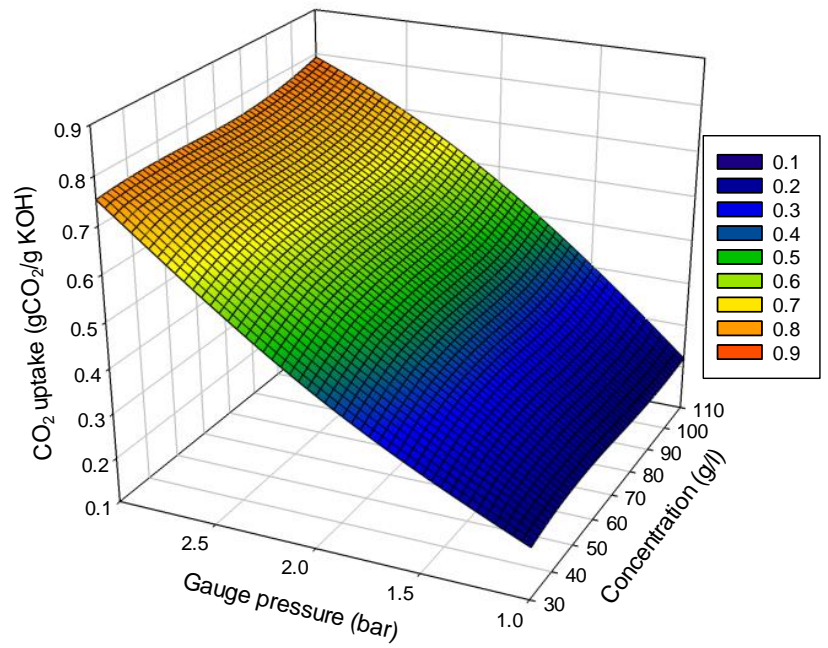

(a)

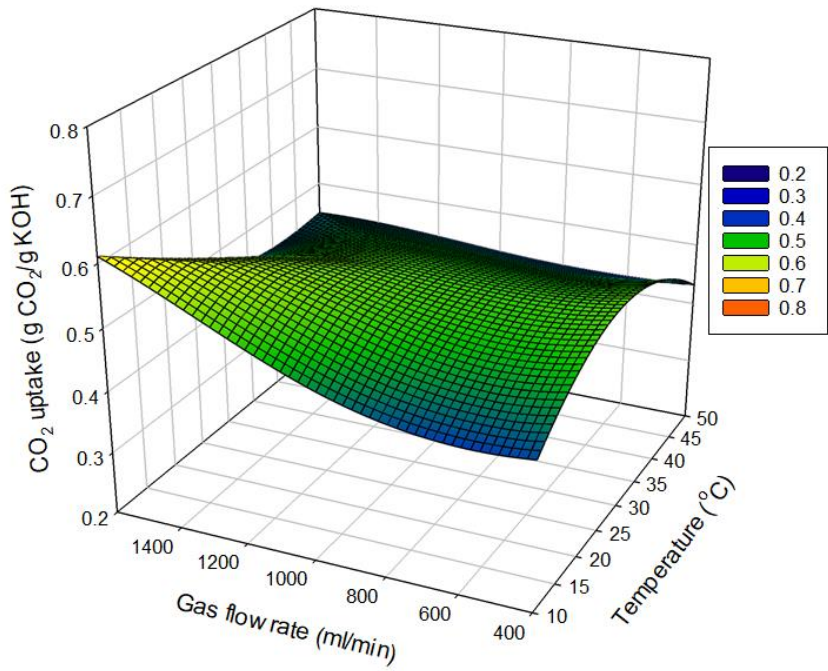

(b)

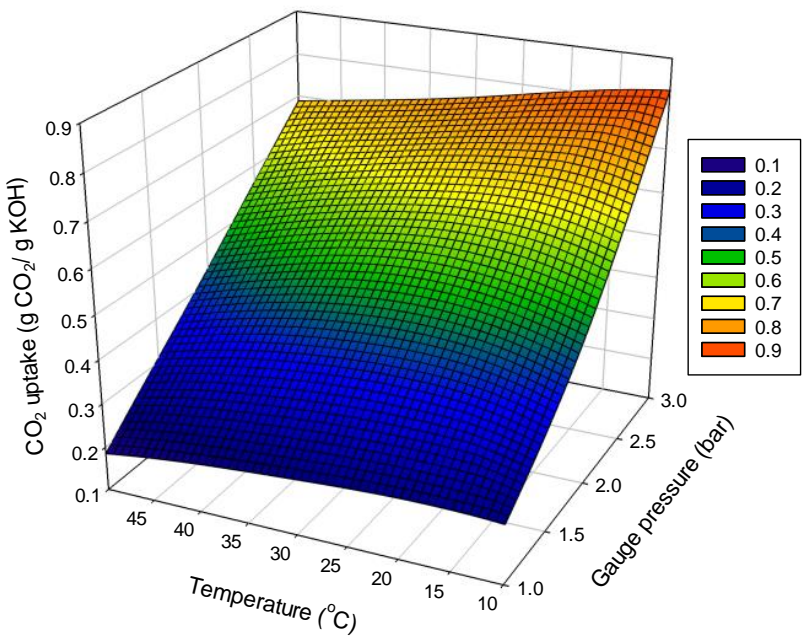

(c)

Figure 2. Response surface plots of the effect of (a) pressure and $\mathrm{KOH}$ concentration, (b) gas flowrate and temperature, and (c) temperature and pressure on $\mathrm{CO}_{2}$ uptake. 


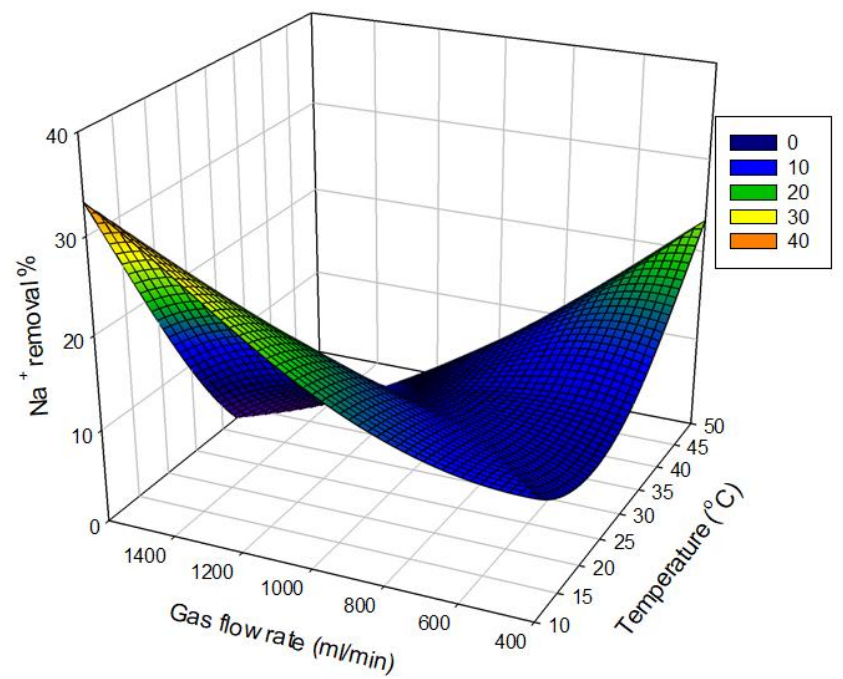

(a)

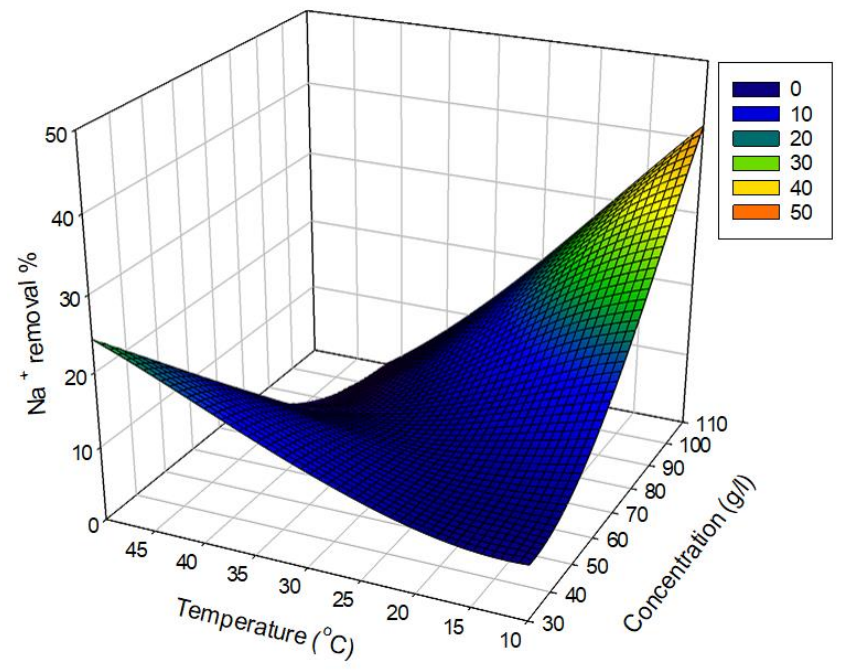

(b)

Figure 3. Surface response plots of the effect of (a) gas flowrate and temperature, and (b) temperature and $\mathrm{KOH}$ concentration, on $\mathrm{Na}^{+}$reduction in reject brine.

Figure $4 \mathrm{a}$ illustrates the influence of gas flowrate and temperature on $\mathrm{Cl}^{-}$reduction at a constant gauge pressure of 2 bar and a $\mathrm{KOH}$ concentration of $70 \mathrm{~g} / \mathrm{L}$. The figure depicts that the maximum $\mathrm{Cl}^{-}$removal is obtained under a maximum temperature of $50{ }^{\circ} \mathrm{C}$ and low gas flowrate of $400 \mathrm{~mL} / \mathrm{min}$. At a low gas flowrate, the gas residence time increased, enhancing the reaction rate and enabling a high removal under relatively high temperature conditions. Notably, owing to the significant effect of the residence time on the overall process performance and reaction rate, the maximum $\mathrm{Cl}^{-}$removal efficiency was obtained at a relatively low $\mathrm{KOH}$ concentration of $50 \mathrm{~g} / \mathrm{L}$ and a low feed-gas flowrate of $400 \mathrm{~mL} / \mathrm{min}$, as illustrated in Figure $4 \mathrm{~b}$. These data were obtained at a temperature of $30{ }^{\circ} \mathrm{C}$ and a gauge pressure of 2 bar.

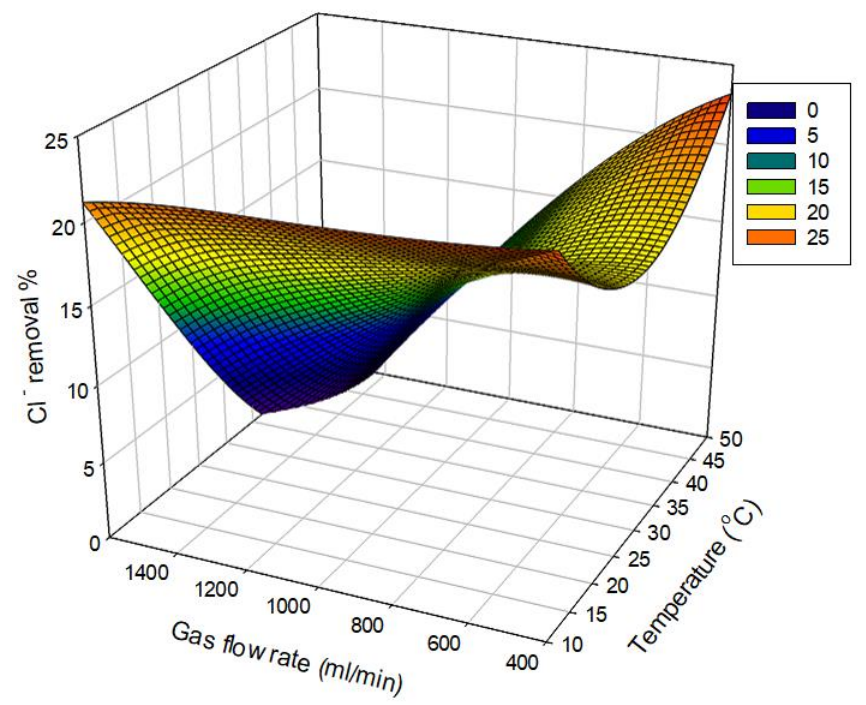

(a)

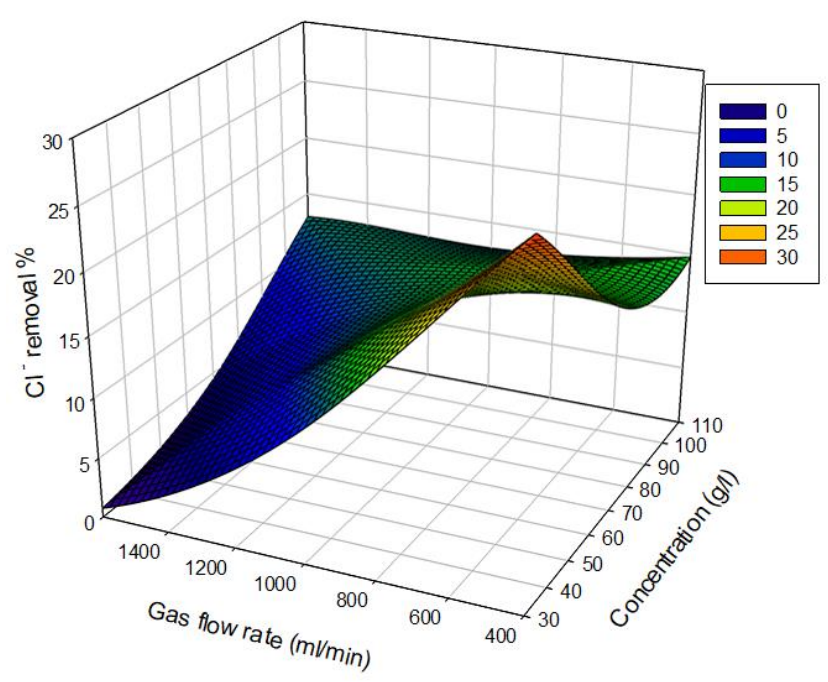

(b)

Figure 4. Surface response plots of the effect of (a) gas flowrate and temperature, and (b) gas flowrate and $\mathrm{KOH}$ concentration, on $\mathrm{Cl}^{-}$reduction in reject brine. 


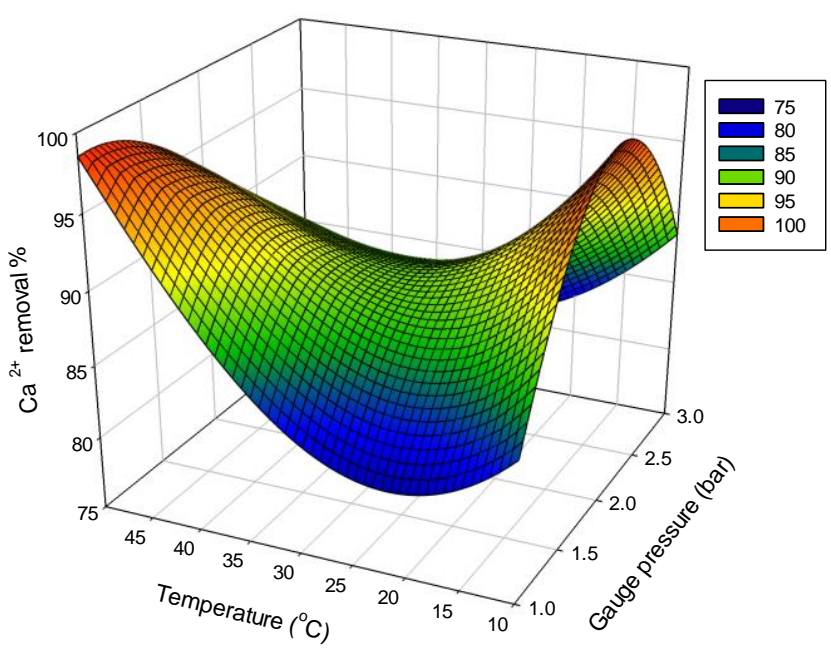

(a)

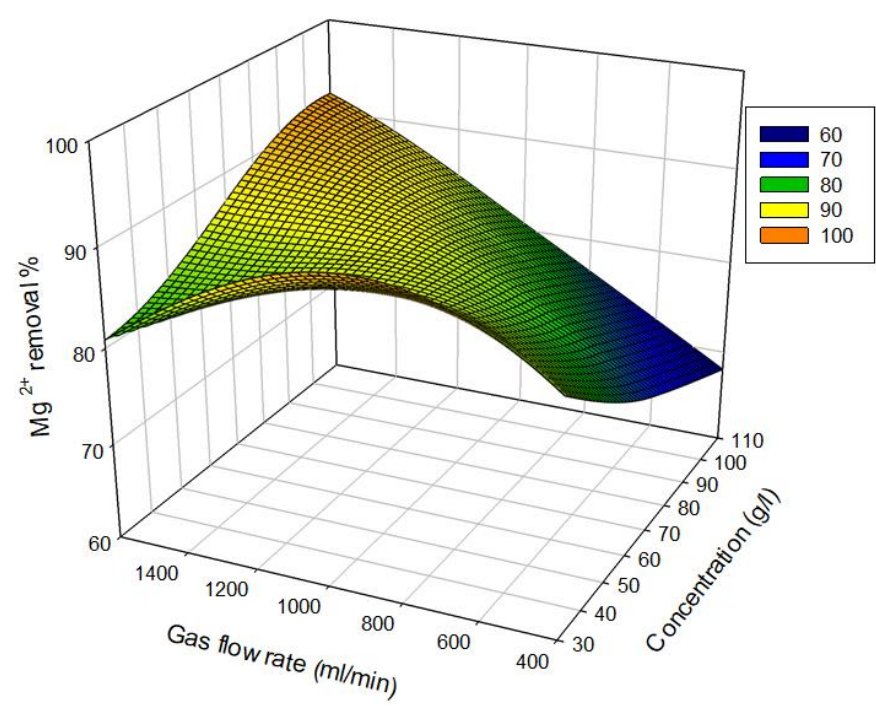

(b)

Figure 5. Surface response plots for the impact of (a) temperature and pressure on $\mathrm{Ca}^{2+}$ reduction, and (b) gas flowrate and $\mathrm{KOH}$ concentration, on $\mathrm{Mg}^{2+}$ reduction in reject brine.

\subsection{Impact of Independent Factors on $\mathrm{Ca}^{2+}$ and $\mathrm{Mg}^{2+}$ Removal from Reject Brine}

The 3D plots of the impact of temperature and pressure on the $\mathrm{Ca}^{2+}$ reduction efficiency are shown in Figure 5a. The figure reveals that high $\mathrm{Ca}^{2+}$ removal values ( 98\%) were obtained at a high temperature value of $50{ }^{\circ} \mathrm{C}$ and a gauge pressure of $1 \mathrm{bar}$. These results, which were obtained at a constant feed-gas flowrate of $1000 \mathrm{~mL} / \mathrm{min}$ and a $\mathrm{KOH}$ concentration of $70 \mathrm{~g} / \mathrm{L}$, can be explained by the high reactivity of $\mathrm{Ca}^{2+}$ with $\mathrm{CO}_{2}$ gas in high-pH media [23]. The interaction effect of gas flowrate and $\mathrm{KOH}$ concentration on $\mathrm{Mg}^{2+}$ reduction is clearly shown in Figure $5 \mathrm{~b}$. These experimental runs were operated at a temperature of $30^{\circ} \mathrm{C}$ and gauge pressure of 2 bar. The maximum $\mathrm{Mg}^{2+}$ reduction efficiency of approximately $95 \%$ was achieved at a high $\mathrm{KOH}$ concentration and high feed-gas flowrate of $110 \mathrm{~g} / \mathrm{L}$ and $1600 \mathrm{~mL} / \mathrm{min}$, respectively. Upon decreasing the gas flowrate to $400 \mathrm{~mL} / \mathrm{min}$ at the same $\mathrm{KOH}$ concentration of $110 \mathrm{~g} / \mathrm{L}$, the $\mathrm{Mg}^{2+}$ removal efficiency was reduced to almost $68 \%$. Thus, a high gas flowrate and high $\mathrm{KOH}$ concentration are essential for enhancing $\mathrm{Mg}^{2+}$ reduction, owing to an improvement in the reaction rate.

\subsection{Process Optimization and Validation}

\subsubsection{Optimization of Responses under Relatively High Temperature Conditions}

Brine is commonly rejected from desalination plants at relatively high temperatures of $40{ }^{\circ} \mathrm{C}$ to $55^{\circ} \mathrm{C}$ [16]. Therefore, the maximum ion reduction that could be reached at $50{ }^{\circ} \mathrm{C}$ was predicted using the response optimizer in Minitab software. Based on the responses of 31 experimental runs, the developed RSM model predicted that the maximum ion reduction can be achieved at a $\mathrm{KOH}$ concentration, gauge pressure, and gas flowrate of $30 \mathrm{~g} / \mathrm{L}$, $2.0 \mathrm{bar}$, and $\sim 776 \mathrm{~mL} / \mathrm{min}$, respectively, under a constant temperature of $50{ }^{\circ} \mathrm{C}$. Table 2 summarizes the predicted optimum conditions, confidence interval (CI), fitted responses, and desirability function. Additionally, a high desirability value of almost 0.85 confirms the optimal performance of the studied parameters [20]. In addition, Figure 6 demonstrates the response optimization plot obtained via Minitab software. It is noticed that a high $\mathrm{KOH}$ concentration has a negative effect on the $\mathrm{Na}^{+}, \mathrm{Cl}^{-}$, and $\mathrm{Mg}^{2+}$ reduction. However, it can positively affect the reduction in $\mathrm{Ca}^{2+}$ ions. The figure also shows a negligible influence of pressure on the $\mathrm{Na}^{+}$removal percentage. It is worth noting that the optimum reduction for all ions can be achieved at a high temperature $\left(50^{\circ} \mathrm{C}\right)$. Moreover, the figure reveals that a low gas flowrate has a good impact on ions removal, except for $\mathrm{Ca}^{2+}$ ions, on which it 
has a negative impact. Therefore, the optimum reduction for all ions can be achieved at an intermediate gas flowrate value of $776 \mathrm{~mL} / \mathrm{min}$.

Table 2. Optimum conditions and fitted responses for ion removal at a high temperature of $50{ }^{\circ} \mathrm{C}$.

\begin{tabular}{cccccc}
\hline Solution & Response & Fits & $95 \% \mathrm{CI}$ & $\begin{array}{c}\text { Composite } \\
\text { Desirability }\end{array}$ \\
\cline { 1 - 4 } $\mathrm{C}(\mathrm{g} / \mathrm{L})$ & 30 & $\mathrm{Na}^{+} \%$ reduction & 53.2 & $(45.20,61.17)$ & \\
\cline { 1 - 4 } $\mathrm{P}($ bar gauge $)$ & 2.0 & $\mathrm{Cl}^{-} \%$ reduction & 24.8 & $(19.87,30.4)$ & \multirow{2}{*}{0.85} \\
\cline { 1 - 4 } $\mathrm{F}(\mathrm{mL} / \mathrm{min})$ & 776 & $\mathrm{Mg}^{2+} \%$ reduction & 92.0 & $(82.95,100)$ & \\
\cline { 1 - 4 } & & $\mathrm{Ca}^{2+} \%$ reduction & 92.8 & $(80.65,100)$ & \\
\hline
\end{tabular}

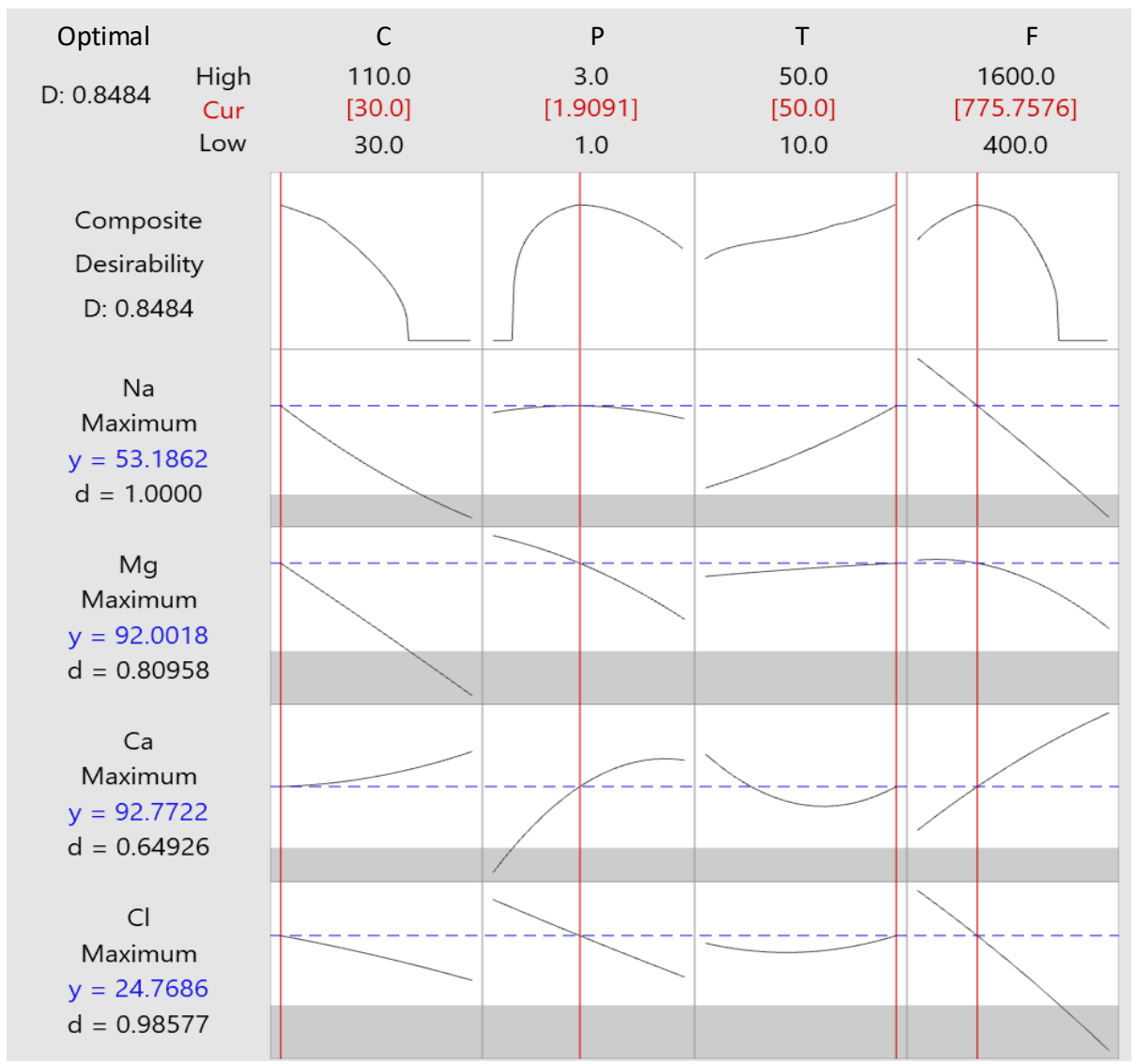

Figure 6. Response optimization plot.

\subsubsection{Experimental Validation of the Predicted Optimal Responses}

The predicted operating conditions and corresponding responses provided in Table 2 were experimentally verified. $\mathrm{Na}^{+}, \mathrm{Cl}^{-}, \mathrm{Mg}^{2+}$, and $\mathrm{Ca}^{2+}$ show a reduction efficiency of up to $45.6 \%, 29.8 \%, 91.2 \%$, and $100 \%$, respectively. All the obtained results were within the $95 \% \mathrm{CI}$ range (Table 2), confirming the ability of the model to predict the performance of the process at several operating parameters. Notably, under the same operating conditions, $\mathrm{CO}_{2}$ uptake reached up to $0.5 \mathrm{~g} \mathrm{CO}_{2} / \mathrm{g} \mathrm{KOH}$, which still constitutes a good level of $\mathrm{CO}_{2}$ capture. The $\mathrm{CO}_{2}$ uptake was expected to decrease when the temperature was increased from $10{ }^{\circ} \mathrm{C}$ to $50{ }^{\circ} \mathrm{C}$. However, owing to the effect of the linear relation between pressure and temperature on $\mathrm{CO}_{2}$ uptake (Figure 2c), the effect of pressure was a good $\mathrm{CO}_{2}$ uptake. 
The results illustrated in Figure 6 show that a high $\mathrm{Na}^{+}$removal efficiency can be achieved at a relatively high temperature of $50{ }^{\circ} \mathrm{C}$, and under certain operating conditions of gas flowrate, $\mathrm{KOH}$ concentration, and pressure. This finding was also confirmed by the validated results. This result can be explained by the so-called hot potassium carbonate $\left(\mathrm{K}_{2} \mathrm{CO}_{3}\right)$ process (hot pot process), according to which $\mathrm{K}_{2} \mathrm{CO}_{3}$ is mainly used to remove large amounts of $\mathrm{CO}_{2}$ from ammonia plants [24-26] via the reaction described in Equation (6) [25]. In this process, the entire system is operated at high temperatures $\left(110-116^{\circ} \mathrm{C}\right)$ to increase the solubility of $\mathrm{K}_{2} \mathrm{CO}_{3}$. Additionally, a relatively high $\mathrm{CO}_{2}$ pressure (2-6 bar gauge) is required to keep $\mathrm{CO}_{2}$ soluble under such high temperature conditions [25]. HSC Chemistry 6.1 software [27] was used to perform a thermodynamic analysis via Equation (6). Table 3 illustrates the calculated thermodynamic properties. The analysis indicates that the reaction is spontaneous for the whole temperature range ( 0 to $\left.100^{\circ} \mathrm{C}\right)$, as indicated by the negative $\Delta \mathrm{G}$.

$$
\mathrm{K}_{2} \mathrm{CO}_{3}+\mathrm{CO}_{2}+\mathrm{H}_{2} \mathrm{O} \leftrightarrow 2 \mathrm{KHCO}_{3}
$$

Table 3. Thermodynamics data of reaction (6).

\begin{tabular}{ccc}
\hline Temperature $\left({ }^{\circ} \mathbf{C}\right)$ & $\Delta \mathbf{H}(\mathbf{k J} / \mathbf{m o l})$ & $\Delta \mathrm{G}(\mathbf{k J} / \mathbf{m o l})$ \\
\hline 0 & -91.662 & -41.917 \\
\hline 10 & -98.143 & -39.867 \\
\hline 20 & -98.611 & -37.801 \\
\hline 30 & -99.072 & -35.718 \\
\hline 40 & -99.525 & -33.621 \\
\hline 50 & -99.971 & -31.51 \\
\hline 60 & -100.409 & -29.384 \\
\hline 70 & -100.839 & -27.246 \\
\hline 80 & -101.261 & -25.095 \\
\hline 90 & -101.676 & -22.933 \\
\hline 100 & -102.083 & -20.759 \\
\hline
\end{tabular}

Note that the $\mathrm{KOH}$ concentration affects the absorption of $\mathrm{CO}_{2}$. An excessive amount of $\mathrm{KOH}$ yields $\mathrm{K}_{2} \mathrm{CO}_{3}$, which competes against the formation of $\mathrm{KHCO}_{3}$ [28]. As shown using Equation (7), the addition of $\mathrm{KOH}$ at amounts equal to or less than the stoichiometric $\mathrm{KOH}$ amount $(70.57 \mathrm{~g} / \mathrm{L})$ would produce bicarbonate ions $\left(\mathrm{HCO}_{3}{ }^{-}\right)$. Alternatively, according to Equation (8), an excess amount of $\mathrm{KOH}$ would yield carbonate ions $\left(\mathrm{CO}_{3}^{2-}\right)$, which are less soluble than $\mathrm{HCO}_{3}{ }^{-}$. Therefore, at low $\mathrm{KOH}$ concentrations $(30 \mathrm{~g} / \mathrm{L})$, the formation reaction of $\mathrm{NaHCO}_{3}$ and $\mathrm{KHCO}_{3}$ is more favorable, resulting in a greater ion reduction.

$$
\begin{gathered}
\mathrm{CO}_{2}+\mathrm{OH}^{-} \leftrightarrow \mathrm{HCO}_{3}^{-} \\
\mathrm{HCO}_{3}^{-}+\mathrm{OH}^{-} \leftrightarrow \mathrm{CO}_{3}^{2-}+\mathrm{H}_{2} \mathrm{O}
\end{gathered}
$$

In summary, the hot pot process and its associated reactions can explain the realization of good $\mathrm{CO}_{2}$ capture and $\mathrm{Na}^{+}$reduction at a relatively high temperature, gauge pressure, gas flowrate, and $\mathrm{KOH}$ concentration of $50{ }^{\circ} \mathrm{C}, 2 \mathrm{bar}, 776 \mathrm{~mL} / \mathrm{min}$, and $30 \mathrm{~g} / \mathrm{L}$, respectively. A high temperature ensures a high solubility of the produced $\mathrm{K}_{2} \mathrm{CO}_{3}$, and simultaneously, a high pressure maintains $\mathrm{CO}_{2}$ gas solubility in the solution, facilitating the reaction described in Equation (6) to proceed. Further, a moderate gas flowrate enhances ion removal because it increases the residence time. Moreover, a low $\mathrm{KOH}$ concentration favors the formation of $\mathrm{HCO}_{3}{ }^{-}$, resulting in the formation of $\mathrm{KHCO}_{3}$ and $\mathrm{NaHCO}_{3}$. At $50{ }^{\circ} \mathrm{C}$, both $\mathrm{KHCO}_{3}$ and $\mathrm{NaHCO}_{3}$ are soluble. However, owing to its high lattice energy, $\mathrm{KHCO}_{3}$ has higher solubility than $\mathrm{NaHCO}_{3}$ [29]. This causes the treated solution to be oversaturated 
with $\mathrm{HCO}_{3}{ }^{-}$; therefore, $\mathrm{KHCO}_{3}$ starts to compete against $\mathrm{NaHCO}_{3}$, resulting in a high precipitation of $\mathrm{NaHCO}_{3}$. This observation was also confirmed by the high precipitation rate of solids when the mixture was collected from the reactor at $50{ }^{\circ} \mathrm{C}$ before the cooling step. The collected mixture was then cooled to allow the precipitation of the rest of the solids, whose characterization confirmed the presence of $\mathrm{KHCO}_{3}$ and $\mathrm{NaHCO}_{3}$. More details about the characterization of the solids are described in Section 4.

\subsubsection{Evaluation of the Optimum Responses at $40{ }^{\circ} \mathrm{C}$ and $60{ }^{\circ} \mathrm{C}$}

Additional experimental runs were conducted at $40{ }^{\circ} \mathrm{C}$ and $60{ }^{\circ} \mathrm{C}$, and the results were compared with those obtained at $50{ }^{\circ} \mathrm{C}$. As shown in Figure $7, \mathrm{CO}_{2}$ uptake reached

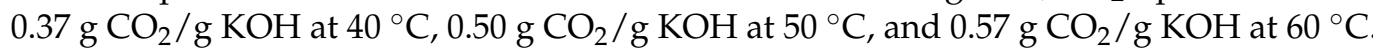
These findings indicate an improvement in $\mathrm{CO}_{2}$ absorption owing to the same reasons given in Section 3.4.2, Equation (6). Figure 8 shows the average ion removal efficiency at different temperatures for three different experimental replicates. Almost the same reduction efficiencies of $91.2 \%$ and $100 \%$ for $\mathrm{Mg}^{2+}$ and $\mathrm{Ca}^{2+}$, respectively, were observed in the entire temperature range. At $40{ }^{\circ} \mathrm{C}$, the $\mathrm{Na}^{+}$and $\mathrm{Cl}^{-}$reduction efficiencies were $40.8 \%$ and $21.47 \%$, respectively. The removal of $\mathrm{Na}^{+}$and $\mathrm{Cl}^{-}$increased to nearly $45.6 \%$ and $29.84 \%$, respectively, at $50{ }^{\circ} \mathrm{C}$, and to $48.1 \%$ and $30.2 \%$, respectively, at $60{ }^{\circ} \mathrm{C}$. Notably, the $\mathrm{K}^{+}$reduction efficiency reached up to $79 \%$ in the entire temperature range. Although $\mathrm{KOH}$ was used as the main alkaline material at high concentrations, a high reduction efficiency was still achieved in the treated brine, confirming the high efficiency of the reaction under the optimized conditions. Table 4 summarizes the main findings from the current research and compares them with recent literature studies for the combined process. It can be noticed that the temperature variation significantly affects the combined process in terms of metal solubility and $\mathrm{CO}_{2}$ capture efficiency. Table 4 also shows that a low temperature is preferred to achieve high $\mathrm{CO}_{2}$ capture and ion removal from reject brine. However, brine is usually discharged at a relatively high temperature range from $40^{\circ} \mathrm{C}$ to $50{ }^{\circ} \mathrm{C}$. The findings of the current work reveal that $\mathrm{CO}_{2}$ and reject brine can be treated under high temperature, as presented in Table 2. This demonstrates the novelty of the $\mathrm{KOH}$-based modified Solvay process.

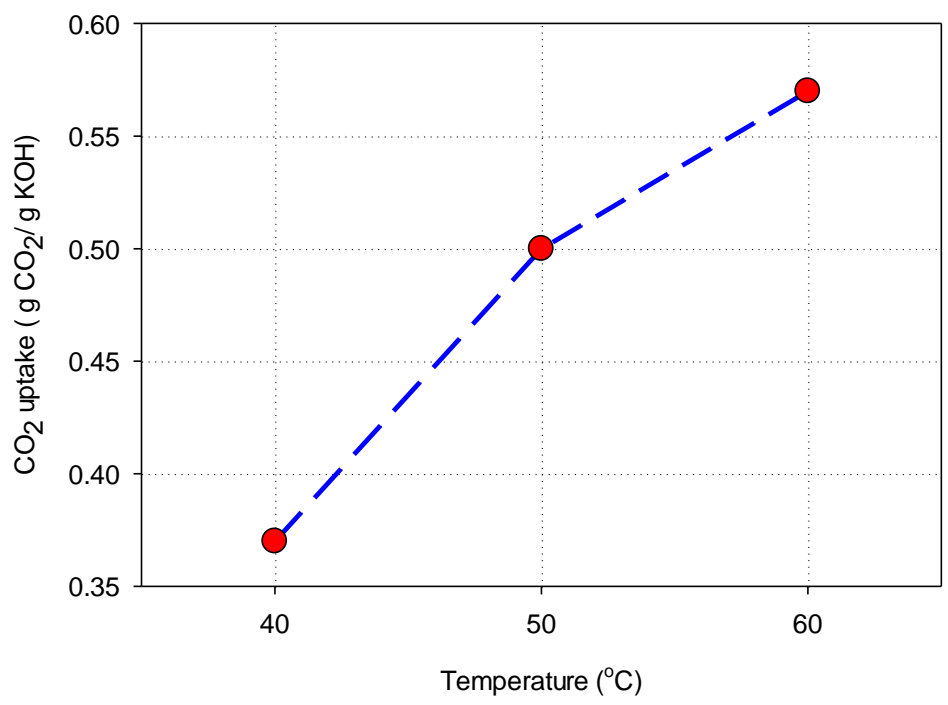

Figure 7. Effect of high temperature on the $\mathrm{CO}_{2}$ uptake at a gauge pressure, $\mathrm{KOH}$ concentration, and gas flowrate of $2 \mathrm{bar}, 30 \mathrm{~g} / \mathrm{L}$, and $776 \mathrm{~mL} / \mathrm{min}$, respectively. 


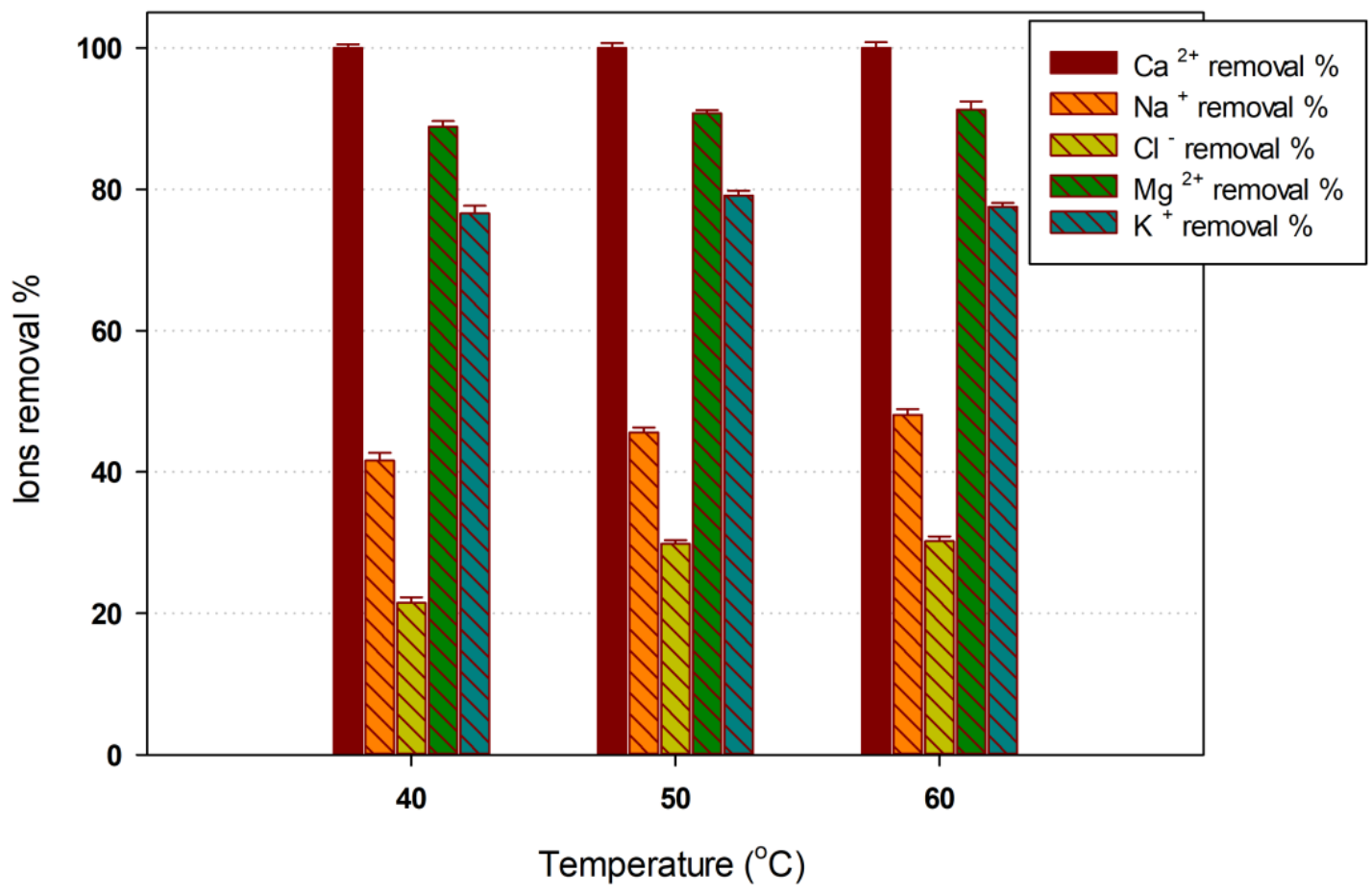

Figure 8. Average ion removal at a gauge pressure, $\mathrm{KOH}$ concentration, and gas flowrate of $2 \mathrm{bar}, 30 \mathrm{~g} / \mathrm{L}$, and $776 \mathrm{~mL} / \mathrm{min}$, respectively.

Table 4. Summary of combined process studies under different operating conditions.

\begin{tabular}{|c|c|c|c|c|c|c|c|}
\hline Reference & Reactants & $\begin{array}{c}\text { Reaction } \\
\text { Temperature }\end{array}$ & $\begin{array}{l}\text { Reaction } \\
\text { Pressure }\end{array}$ & $\mathrm{pH}$ & $\begin{array}{c}\mathrm{Na}^{+} \\
\text {Removal } \\
\text { Efficiency }\end{array}$ & $\begin{array}{c}\mathrm{CO}_{2} \\
\text { Capture } \\
\text { Efficiency }\end{array}$ & $\begin{array}{l}\text { Main } \\
\text { Products }\end{array}$ \\
\hline $\begin{array}{l}\text { Mohammad et al. } \\
{[2]}\end{array}$ & $\begin{array}{l}\text { Ammoniated } \\
\text { brine is used to } \\
\text { capture } \mathrm{CO}_{2} \\
\text { according to } \\
\text { Equation (1) }\end{array}$ & $19^{\circ} \mathrm{C}$ & 1 bar & 11.2 & $33 \%$ & $86 \%$ & $\begin{array}{c}\mathrm{NaHCO}_{3} \\
\mathrm{NH}_{4} \mathrm{Cl}\end{array}$ \\
\hline $\begin{array}{l}\text { Palitsakun et al., } \\
2019 \text { [3] }\end{array}$ & $\begin{array}{c}\text { Carbonation of } \\
\text { ammoniated } \\
\text { brine }\end{array}$ & 20 to $38^{\circ} \mathrm{C}$ & $\mathrm{N} / \mathrm{A}$ & $\mathrm{N} / \mathrm{A}$ & $\mathrm{N} / \mathrm{A}$ & $\begin{array}{l}\sim 93 \text { at } 20^{\circ} \mathrm{C} \\
80 \% \text { at } 38^{\circ} \mathrm{C}\end{array}$ & $\begin{array}{c}\mathrm{NaHCO}_{3} \\
\mathrm{Na}_{2} \mathrm{CO}_{3} \\
\mathrm{NH}_{4} \mathrm{HCO}_{3} \\
\left(\mathrm{NH}_{4}\right)_{2} \mathrm{CO}_{3} \\
\mathrm{CaCO}_{3}\end{array}$ \\
\hline $\begin{array}{c}\text { El-Naas et al. } \\
{[4,5]}\end{array}$ & $\begin{array}{l}\text { Reject brine is } \\
\text { reacted with } \mathrm{CaO} \\
\text { to capture } \mathrm{CO}_{2}, \\
\text { according to } \\
\text { Equation }(2)\end{array}$ & 20 to $50^{\circ} \mathrm{C}$ & $1 \mathrm{bar}$ & 11.8 & $\begin{array}{l}35 \text { at } 20^{\circ} \mathrm{C} \\
5 \% \text { at } 50{ }^{\circ} \mathrm{C}\end{array}$ & $\begin{array}{l}98 \% \text { at } 20^{\circ} \mathrm{C} \\
\sim 45 \% \text { at } 50^{\circ} \mathrm{C}\end{array}$ & $\begin{array}{c}\mathrm{NaHCO}_{3} \\
\mathrm{CaCO}_{3} \\
\mathrm{CaCl}_{2}\end{array}$ \\
\hline $\begin{array}{l}\text { Dindi et al., } \\
2018 \text { [6] }\end{array}$ & $\begin{array}{l}\text { Mixed magne- } \\
\text { sium/aluminum } \\
\text { oxides }\end{array}$ & $25^{\circ} \mathrm{C}$ & 1 bar & 10 & $20 \%$ & $\begin{array}{l}0.082 \mathrm{~g} \\
\mathrm{CO}_{2} / \mathrm{g} \\
\text { carbonated } \\
\text { solution }\end{array}$ & $\mathrm{NaHCO}_{3}$ \\
\hline $\begin{array}{l}\text { Shim et al., } \\
2016 \text { [7] }\end{array}$ & $\begin{array}{c}\mathrm{NaOH} \\
\text { reacted } \\
\text { with } \mathrm{CO}_{2}\end{array}$ & $\begin{array}{c}\text { Ambient } \\
\text { temperature }\end{array}$ & 1 bar & $9.0-12.5$ & $\mathrm{~N} / \mathrm{A}$ & $>95 \%$ & $\begin{array}{c}97 \% \text { of } \\
\mathrm{NaHCO}_{3}\end{array}$ \\
\hline
\end{tabular}


Table 4. Cont.

\begin{tabular}{|c|c|c|c|c|c|c|c|}
\hline Reference & Reactants & $\begin{array}{c}\text { Reaction } \\
\text { Temperature }\end{array}$ & $\begin{array}{l}\text { Reaction } \\
\text { Pressure }\end{array}$ & $\mathrm{pH}$ & $\begin{array}{c}\mathrm{Na}^{+} \\
\text {Removal } \\
\text { Efficiency }\end{array}$ & $\begin{array}{c}\mathrm{CO}_{2} \\
\text { Capture } \\
\text { Efficiency }\end{array}$ & $\begin{array}{c}\text { Main } \\
\text { Products }\end{array}$ \\
\hline Ibrahim et al. [8] & $\begin{array}{l}\text { Reject brine is } \\
\text { reacted with } \mathrm{BHD} \\
\text { to capture } \mathrm{CO}_{2}\end{array}$ & $\begin{array}{c}\text { Ambient } \\
\text { temperature }\end{array}$ & 5 bar & 11 & $\mathrm{~N} / \mathrm{A}$ & $\begin{array}{c}(1 \pm 0.04) \mathrm{g} \\
\mathrm{CO}_{2} / \mathrm{g} \mathrm{BHD}\end{array}$ & $\begin{array}{c}\mathrm{NaHCO}_{3} \\
\mathrm{CaCO}_{3} \\
\mathrm{CaCl}_{2}\end{array}$ \\
\hline Current Study & $\begin{array}{l}\text { Reject brine is } \\
\text { reacted with } \mathrm{KOH} \\
\text { to capture } \mathrm{CO}_{2} \\
\text { according to } \\
\text { Equation (2) }\end{array}$ & $50{ }^{\circ} \mathrm{C}$ & 2 bar gauge & 13.6 & $45.6 \%$ & $\begin{array}{c}0.50 \mathrm{~g} \mathrm{CO}_{2} / \mathrm{g} \\
\mathrm{KOH}\end{array}$ & $\begin{array}{c}\mathrm{NaHCO}_{3} \\
\mathrm{KCl}\end{array}$ \\
\hline
\end{tabular}

\section{Characterization of Solid Products Obtained under Optimized Conditions}

\subsection{XRD Analysis of Solids Obtained at $40^{\circ} \mathrm{C}, 50^{\circ} \mathrm{C}$, and $60^{\circ} \mathrm{C}$}

The structural properties of the collected samples were examined using an X-ray diffractometer with $\mathrm{Cu} \mathrm{K} \alpha$ radiation $(\lambda=1.54 \AA)$. All measurements were performed using a tube current of $30 \mathrm{~mA}$ and a target voltage of $40 \mathrm{kV}$. The scanning range was set at $2 \theta$ values of $5-70^{\circ}$ to cover all significant diffraction peaks at a scan speed of $2^{\circ} / \mathrm{min}$. The XRD spectra of the three samples are shown in Figure 9. The XRD diffraction peaks of the collected solids were identified according to the theoretical intensity of the three most intense peaks for the mineral in a pure state [30,31]. The characterization of the collected solids confirmed the recovery of brine salts in the form of $\mathrm{CaCO}_{3}, \mathrm{KCl}, \mathrm{KHCO}_{3}$, $\mathrm{K}_{2} \mathrm{CO}_{3}, \mathrm{Mg}(\mathrm{OH})_{2}$, and $\mathrm{NaHCO}_{3}$. A clear change in the structural properties was observed when the reaction temperature was increased. The reaction conditions significantly change the intensity of the XRD peaks of the collected solids. The produced solids have many applications in various industrial fields. $\mathrm{NaHCO}_{3}$ can be used as a $\mathrm{pH}$ buffering agent $[4,32]$. $\mathrm{KCl}$ is used in the production of crop fertilizers $(95 \%$ of the fertilizers in the USA are supplied in the form of $\mathrm{KCl}$ [33]) and has medical applications [34]. $\mathrm{KCl}$ can also be reused in the production of $\mathrm{KOH}$ through the electrolysis process [35], according to Equation (9), which confirms the sustainability of this promising alkaline $(\mathrm{KOH})$ in the modified Solvay process. $\mathrm{K}_{2} \mathrm{CO}_{3}$ and/or bicarbonate $\mathrm{KHCO}_{3}$ are largely used as cleaning and emulsifying agents [36].

$$
2 \mathrm{KCl}+2 \mathrm{H}_{2} \mathrm{O} \rightarrow 2 \mathrm{KOH}+\mathrm{Cl}_{2}+\mathrm{H}_{2}
$$

\subsection{SEM Analysis of Solids Obtained at $40^{\circ} \mathrm{C}, 50^{\circ} \mathrm{C}$, and $60^{\circ} \mathrm{C}$}

The surface morphology, texture, and shape of the collected solid samples were characterized using SEM in three different areas. Before the SEM analysis, the samples were coated with a thin gold film, and then average energy dispersive X-ray spectroscopy (EDS) analysis was performed to detect the main elements in the sample. The SEM micrographs of the cross-sections of the samples obtained under the optimum conditions exhibited clear morphological structures (Figure 10). A specific morphological structure was observed at each temperature; for example, under the optimum conditions $(\mathrm{KOH}$ concentration $=30 \mathrm{~g} / \mathrm{L}$, gauge pressure $=2 \mathrm{bar}$, and gas flowrate $=776 \mathrm{~mL} / \mathrm{min}$ ) and $40^{\circ} \mathrm{C}$, elongated rod agglomerates with spheroidal particles were visible (Figure 10a). The elongated rods correspond to $\mathrm{NaHCO}_{3}$ crystals [37]. When the reaction temperature was increased up to $50^{\circ} \mathrm{C}$ (Figure 10b), a higher number of spheroidal particles and a lower concentration of elongated rods were detected in the general structure. Figure 10c shows the morphology of the samples at $60{ }^{\circ} \mathrm{C}$. In this figure, the elongated rods completely disappeared; instead, uniform spheroidal particles and smaller shell-shaped crystals were detected. The production of more $\mathrm{KHCO}_{3}$ and $\mathrm{NaHCO}_{3}$ can explain the change in the morphology of the samples from elongated rods to spheroidal particles [38,39]. These findings were also confirmed by the average particle size, which reached a minimum value of $15-25 \mu \mathrm{m}$ at a high temperature of $60^{\circ} \mathrm{C}$ (Figure 11). EDS analysis was also 
conducted, which confirmed the results obtained using XRD analysis and showed that the main elements in the collected solids were $\mathrm{Na}, \mathrm{Ca}, \mathrm{Mg}, \mathrm{C}, \mathrm{O}, \mathrm{K}$, and $\mathrm{Cl}$ (Figure 10a-c).

\subsection{FTIR Spectroscopy Analysis of Solids Obtained at $40^{\circ} \mathrm{C}, 50^{\circ} \mathrm{C}$, and $60^{\circ} \mathrm{C}$}

The collected solid samples were examined using FTIR analysis by employing an IRTrace-100 FTIR spectrophotometer (Shimadzu, Kyoto, Japan) to investigate the presence of functional groups. The spectra were recorded in a wavenumber range of $500-4000 \mathrm{~cm}^{-1}$ using a spectral resolution of $4 \mathrm{~cm}^{-1}$ and 34 scans. Figure 12 shows the spectra of the solids obtained at $40{ }^{\circ} \mathrm{C}, 50^{\circ} \mathrm{C}$, and $60^{\circ} \mathrm{C}$. Many absorption bands with a clear difference were observed between the samples. In all the spectra, a band appearing at $3250-3750 \mathrm{~cm}^{-1} \mathrm{can}$ be attributed to the $\mathrm{OH}$ groups and a peak at $2750-3000 \mathrm{~cm}^{-1}$ corresponded to the $\mathrm{C}-\mathrm{H}$ stretching. An absorption band attributed to $\mathrm{CO}_{3}^{2-}$ was clearly detected at $1250-1750 \mathrm{~cm}^{-1}$.

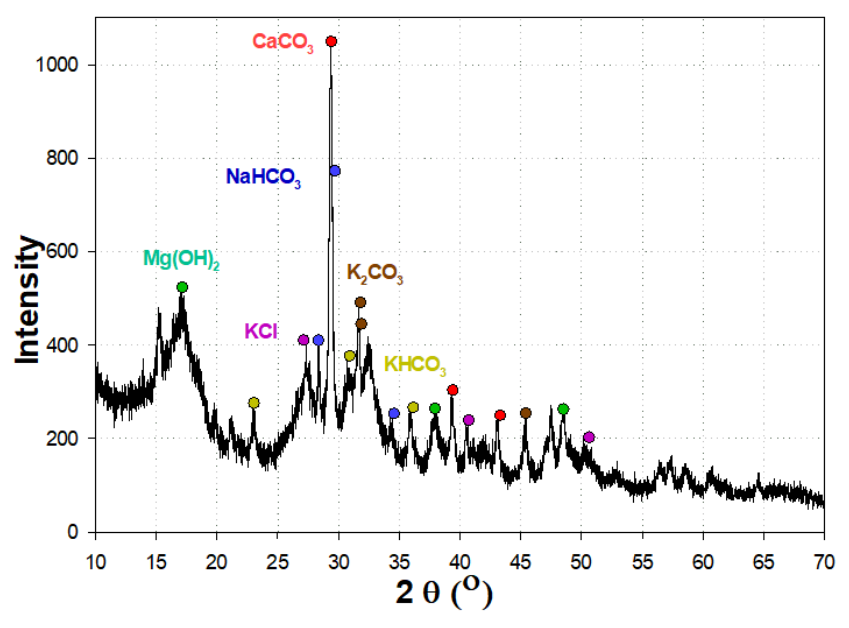

(a)

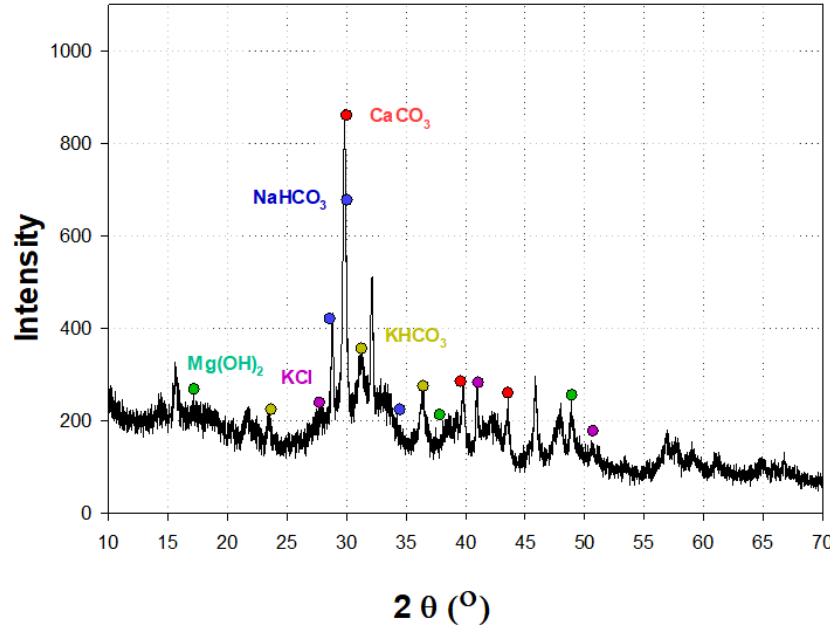

(b)

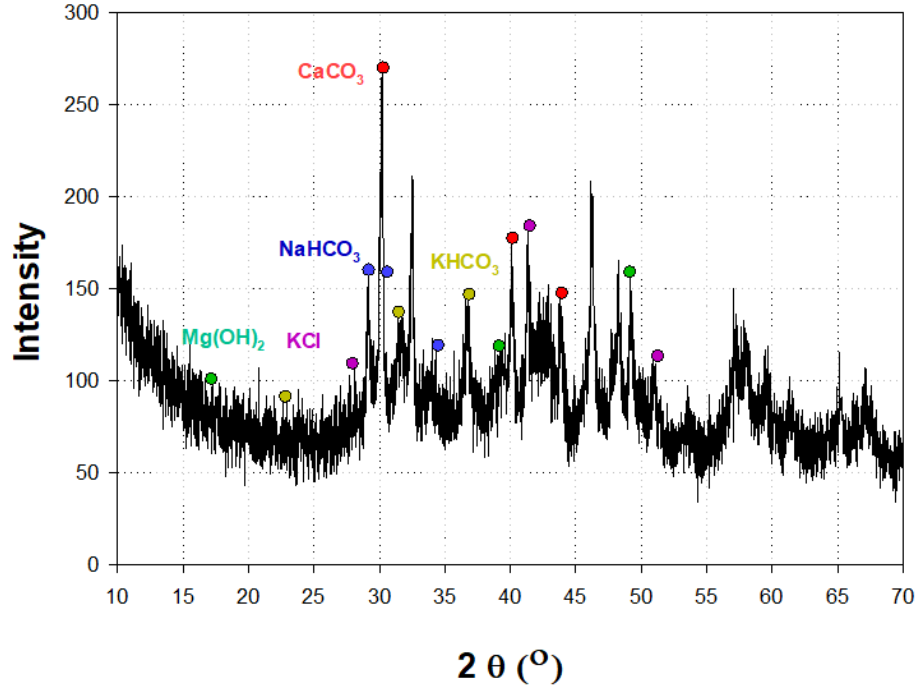

(c)

Figure 9. X-ray diffraction patterns of dried and collected solids under optimized conditions $(\mathrm{KOH}$ concentration $=30 \mathrm{~g} / \mathrm{L}$, gauge pressure $=2$ bar, gas flowrate $=776 \mathrm{~mL} / \mathrm{min}$ ) and temperatures of (a) $40^{\circ} \mathrm{C},(\mathbf{b}) 50{ }^{\circ} \mathrm{C}$, and (c) $60{ }^{\circ} \mathrm{C}$. 


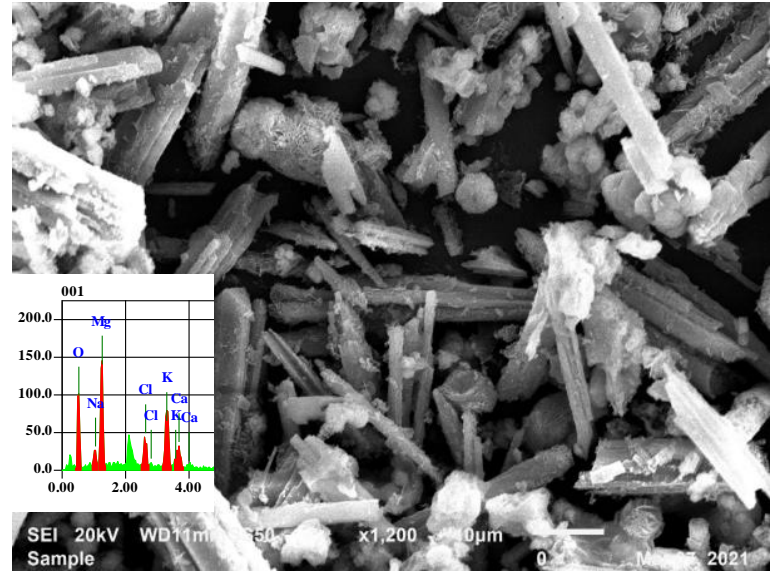

(a)

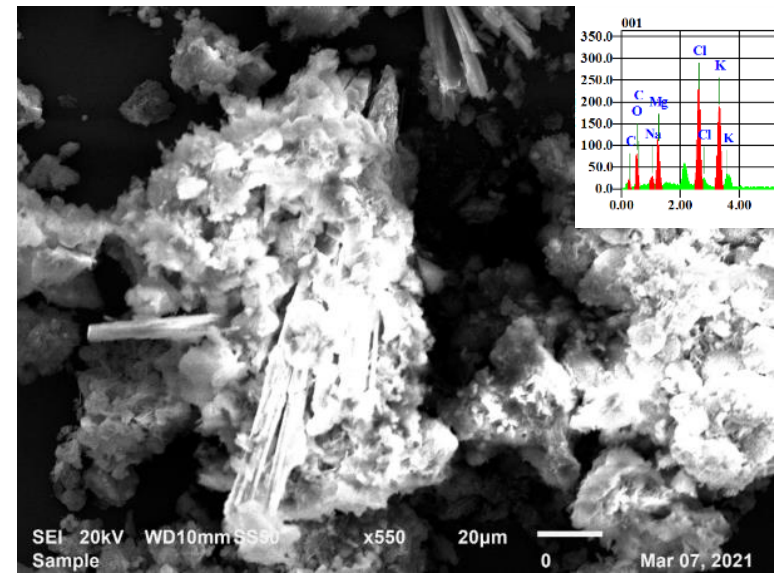

(b)

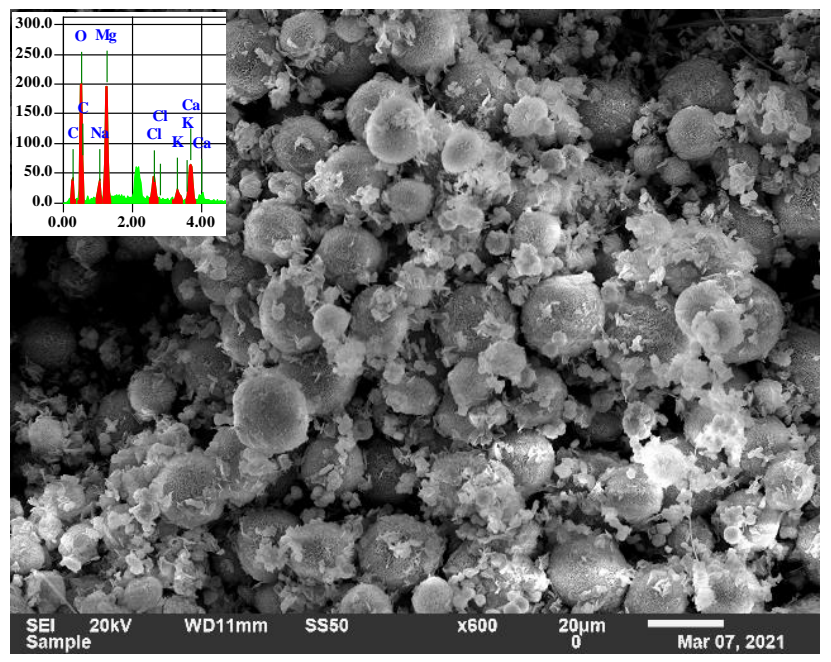

(c)

Figure 10. Cross-section scanning electron microscopy images of the solids obtained under optimized conditions (KOH concentration $=30 \mathrm{~g} / \mathrm{L}$, gauge pressure $=2$ bar, gas flowrate $=776 \mathrm{~mL} / \mathrm{min}$ ) and temperatures of (a) $40{ }^{\circ} \mathrm{C},(\mathbf{b}) 50{ }^{\circ} \mathrm{C}$, and (c) $60^{\circ} \mathrm{C}$.

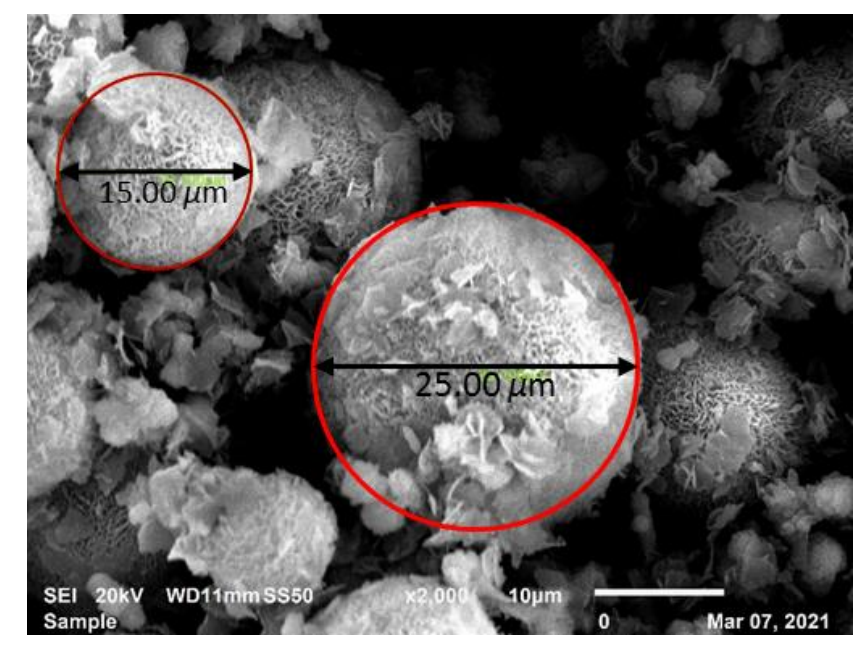

Figure 11. Cross-section scanning electron microscopy images of the solids obtained under optimized conditions $(\mathrm{KOH}$ concentration $=30 \mathrm{~g} / \mathrm{L}$, gauge pressure $=2 \mathrm{bar}$, gas flowrate $=776 \mathrm{~mL} / \mathrm{min}$ ) and $60{ }^{\circ} \mathrm{C}$, showing the average particle size distribution. 


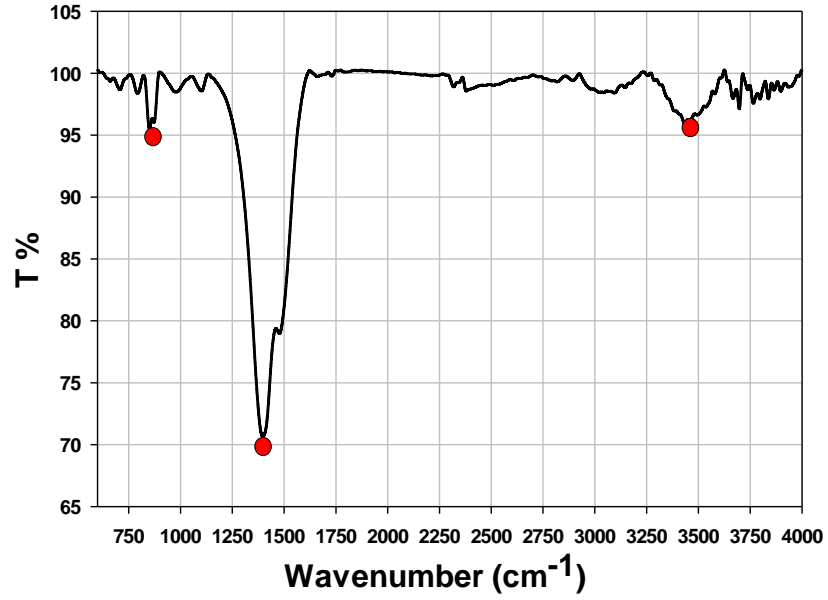

(a)

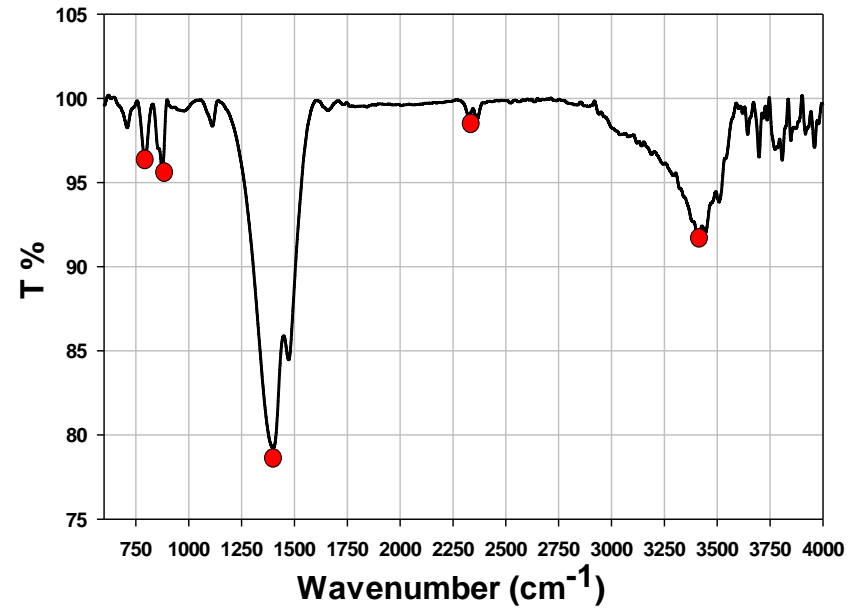

(b)

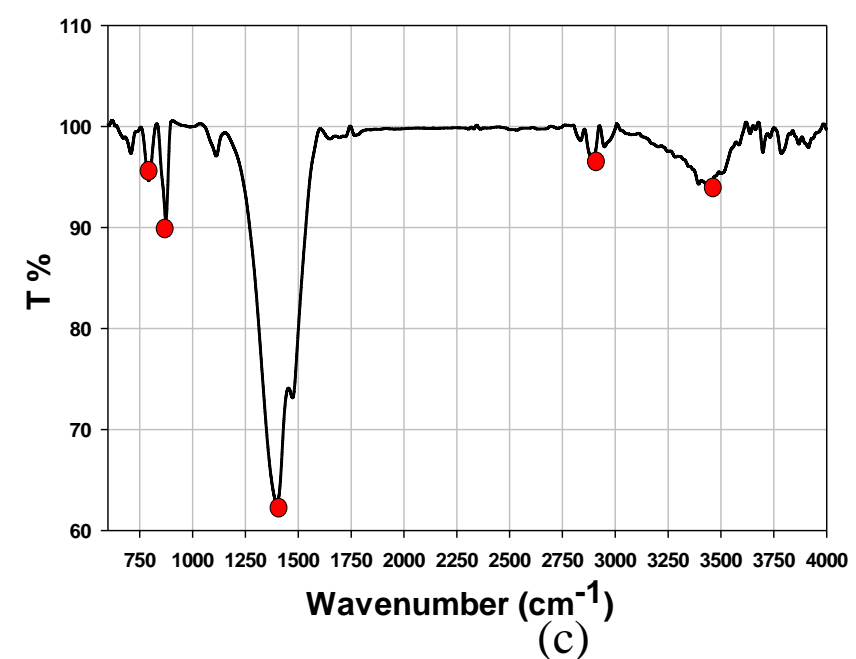

Figure 12. Fourier transform infrared spectra of the solids obtained under optimized conditions ( $\mathrm{KOH}$ concentration $=30 \mathrm{~g} / \mathrm{L}$, gauge pressure $=2 \mathrm{bar}$, gas flowrate $=776 \mathrm{~mL} / \mathrm{min})$ and temperatures of $(\mathbf{a}) 40{ }^{\circ} \mathrm{C},(\mathbf{b}) 50{ }^{\circ} \mathrm{C}$, and (c) $60^{\circ} \mathrm{C}$.

\section{Conclusions}

The optimization of the $\mathrm{KOH}$-based modified Solvay process was performed under different operating conditions to obtain the maximum $\mathrm{CO}_{2}$ capture and ion recovery from reject brine at a relatively high temperature of $50^{\circ} \mathrm{C}$. An RSM-based CCD approach using Minitab 19.0 was implemented to predict and optimize the effects of four important factors on the responses, namely, $\mathrm{KOH}$ concentration (30-110 g/L), gauge pressure (1-3 bar), temperature $\left(10{ }^{\circ} \mathrm{C}-50{ }^{\circ} \mathrm{C}\right)$, and $\mathrm{CO}_{2}$ gas flowrate $(400-1600 \mathrm{~mL} / \mathrm{min})$. The responses of 31 experimental runs were properly represented using 3D surface response plots. A response optimizer was used to predict the optimum conditions to achieve the maximum responses by holding the temperature at $50{ }^{\circ} \mathrm{C}$. The predicted optimum conditions were obtained at a gauge pressure, gas flowrate, and $\mathrm{KOH}$ concentration of $2 \mathrm{bar}, 776 \mathrm{~mL} / \mathrm{min}$, and $30 \mathrm{~g} / \mathrm{L}$, respectively. The predicted responses under these conditions were experimentally validated, and the results showed a good agreement with the predicted values. The experimental results showed that under the optimized conditions and at $50^{\circ} \mathrm{C}$, a maximum $\mathrm{CO}_{2}$ uptake of $\sim 0.50 \mathrm{~g} \mathrm{CO}_{2} / \mathrm{g} \mathrm{KOH}$ and maximum reduction efficiencies of $\mathrm{Na}^{+}, \mathrm{Cl}^{-}, \mathrm{Ca}^{2+}$, and $\mathrm{Mg}^{2+}$ of $45.6 \%, 29.8 \%, 100 \%$, and $91.2 \%$, respectively, were achieved. Under these operating conditions, the reaction rate was relatively high, and a new reaction occurred. This can be explained by the hot pot process of $\mathrm{K}_{2} \mathrm{CO}_{3}$, during which the pressurized $\mathrm{CO}_{2}$ reacts with soluble $\mathrm{K}_{2} \mathrm{CO}_{3}$ at high temperatures to form $\mathrm{KHCO}_{3}$. The solid products 
were characterized using SEM, XRD, and FTIR analysis. All the results confirmed the production of valuable products with diverse industrial applications, such as $\mathrm{NaHCO}_{3}$, $\mathrm{KHCO}_{3}, \mathrm{~K}_{2} \mathrm{CO}_{3}$, and $\mathrm{KCl}$.

Author Contributions: Conceptualization, M.H.E.-N. and A.H.A.-M.; methodology, A.A-H.I.M. and A.F.M.; software, M.A.; validation, M.H.E.-N., A.F.M. and A.A-H.I.M.; formal analysis, A.A-H.I.M.; investigation, A.F.M.; resources, A.H.A.-M.; writing-original draft preparation, A.A-H.I.M.; writing-review and editing, M.H.E.-N. and A.F.M.; visualization, M.H.A.-M.; supervision, A.H.A.-M. All authors have read and agreed to the published version of the manuscript.

Funding: This research received no external funding.

Conflicts of Interest: The authors declare no conflict of interest.

\section{References}

1. Mustafa, J.; Mourad, A.A-H.I.; Al-Marzouqi, A.H.; El-Naas, M.H. Simultaneous treatment of reject brine and capture of carbon dioxide: A comprehensive review. Desalination 2020, 483, 114386. [CrossRef]

2. Mohammad, A.F.; El-Naas, M.H.; Suleiman, M.I.; Al Musharfy, M. Optimization of a Solvay-Based Approach for $\mathrm{CO}_{2}$ Capture. Int. J. Chem. Eng. Appl. 2016, 7, 230-234. [CrossRef]

3. Palitsakun, S.; Seubsai, A.; Sudsakorn, $\mathrm{K} . \mathrm{CO}_{2}$ capture in the form of thermally stable solid compounds using ammoniated brine. Songklanakarin J. Sci. Technol. 2019, 41, 984-991.

4. El-Naas, M.H.; Mohammad, A.F.; Suleiman, M.I.; Al Musharfy, M.; Al-Marzouqi, A.H. A new process for the capture of $\mathrm{CO}_{2}$ and reduction of water salinity. Desalination 2017, 411, 69-75. [CrossRef]

5. El-Naas, M.H. Process for Capture of Carbon Dioxide and Desalination. U.S. Patent 10,118,843, 6 November 2018.

6. Dindi, A.; Quang, D.V.; AlNashef, I.; Abu-Zahra, M.R.M. A process for combined $\mathrm{CO}_{2}$ utilization and treatment of desalination reject brine. Desalination 2018, 442, 62-74. [CrossRef]

7. Shim, J.-G.; Lee, D.W.; Lee, J.H.; Kwak, N.-S. Experimental study on capture of carbon dioxide and production of sodium bicarbonate from sodium hydroxide. Environ. Eng. Res. 2016, 21, 297-303. [CrossRef]

8. Ibrahim, M.H.; El-Naas, M.H.; Zevenhoven, R.; Al-Sobhi, S.A. Enhanced $\mathrm{CO}_{2}$ capture through reaction with steel-making dust in high salinity water. Int. J. Greenh. Gas Control 2019, 91, 102819. [CrossRef]

9. Mourad, A.A-H.I.; Mohammad, A.F.; Altarawneh, M.; Al-Marzouqi, A.H.; El-Naas, M.H.; Al-Marzouqi, M.H. Effects of potassium hydroxide and aluminum oxide on the performance of a modified solvay process for $\mathrm{CO}_{2}$ capture: A comparative study. Int. J. Energy Res. 2021, 45, 13952-13964. [CrossRef]

10. Gambhir, A.; Tavoni, M. Direct air carbon capture and sequestration: How it works and how it could contribute to climate-change mitigation. One Earth 2019, 1, 405-409. [CrossRef]

11. Bandi, A.; Specht, M.; Weimer, T.; Schaber, $\mathrm{K} . \mathrm{CO}_{2}$ recycling for hydrogen storage and transportation-Electrochemical $\mathrm{CO}_{2}$ removal and fixation. Energy Convers. Manag. 1995, 36, 899-902. [CrossRef]

12. Lendzion-Bieluń, Z.; Czekajło, Ł.; Sibera, D.; Moszyński, D.; Sreńscek-Nazzal, J.; Morawski, A.W.; Wrobel, R.J.; Michalkiewicz, B.; Arabczyk, W.; Narkiewicz, U. Surface characteristics of $\mathrm{KOH}$-treated commercial carbons applied for $\mathrm{CO}_{2}$ adsorption. Adsorpt. Sci. Technol. 2018, 36, 478-492. [CrossRef]

13. Keith, D.W.; Holmes, G.; Angelo, D.S.; Heidel, K. A process for capturing $\mathrm{CO}_{2}$ from the atmosphere. Joule 2018, 2, 1573-1594. [CrossRef]

14. Lombardia, L.; Corti, A.; Carnevale, E.; Baciocchi, R.; Zingaretti, D. Carbon dioxide removal and capture for landfill gas up-grading. Energy Procedia 2011, 4, 465-472. [CrossRef]

15. Mohammad, N.K.; Ghaemi, A.; Tahvildari, K. Hydroxide modified activated alumina as an adsorbent for $\mathrm{CO}_{2}$ adsorption: Experimental and modeling. Int. J. Greenh. Gas Control 2019, 88, 24-37. [CrossRef]

16. Liu, Q.; Maroto-Valer, M.M. Studies of $\mathrm{pH}$ buffer systems to promote carbonate formation for $\mathrm{CO}_{2}$ sequestration in brines. Fuel Process. Technol. 2012, 98, 6-13. [CrossRef]

17. El-Naas, M.H. System for contacting gases and liquids. U.S. Patent 9724639B2, 8 August 2017.

18. El-Naas, M.H.; Mohammad, A.F.; Suleiman, M.I.; Al Musharfy, M.; Al-Marzouqi, A.H. Evaluation of a novel gas-liquid contactor/reactor system for natural gas applications. J. Nat. Gas Sci. Eng. 2017, 39, 133-142. [CrossRef]

19. Mohammad, A.F.; Mourad, A.A-H.I.; Mustafa, J.; Al-Marzouqi, A.H.; El-Naas, M.H.; Al-Marzouqi, M.H.; Alnaimat, F.; Suleiman, M.I.; Al Musharfy, M.; Firmansyah, T. Computational fluid dynamics simulation of an Inert Particles Spouted Bed Reactor (IPSBR) system. Int. J. Chem. React. Eng. 2020, 1. [CrossRef]

20. Mohammad, A.; Mourad, A.A-H.I.; Al-Marzouqi, A.H.; El-Naas, M.H.; Van der Bruggen, B.; Al-Marzouqi, M.; Alnaimat, F.; Suleiman, M.; Al Musharfy, M. CFD and statistical approach to optimize the average air velocity and air volume fraction in an inert-particles spouted-bed reactor (IPSBR) system. Heliyon 2021, 7, e06369. [CrossRef] 
21. Mohammad, A.F.; Mourad, A.A-H.I.; Mustafa, J.; Al-Marzouqi, A.H.; El-Naas, M.H.; Al-Marzouqi, M.H.; Van der Bruggen, B.; Suleiman, M.I.; Al Musharfy, M. A CFD Investigation on the Effect of IPSBR Operational Conditions on Liquid Phase Hydrodynamics. In Proceedings of the 2021 6th International Conference on Renewable Energy: Generation and Applications (ICREGA), Al Ain, United Arab Emirates, 2-4 February 2021; pp. 153-157.

22. Mourad, A.A-H.I.; Ghasem, N.M.; Alraeesi, A.Y. Modelling and simulation of hydrogen production via water gas shift membrane reactor. Int. J. Chem. Eng. Appl. 2018, 9, 112-118. [CrossRef]

23. Kodama, S.; Nishimoto, T.; Yamamoto, N.; Yogo, K.; Yamada, K. Development of a new pH-swing $\mathrm{CO}_{2}$ mineralization process with a recyclable reaction solution. Energy 2008, 33, 776-784. [CrossRef]

24. Fahim, M.A.; Alsahhaf, T.A.; Elkilani, A. (Eds.) Chapter 17-Environmental Aspects in Refining. In Fundamentals of Petroleum Refining; Elsevier: Amsterdam, The Netherlands, 2010; pp. 423-455.

25. Feron, P. Absorption-Based Post-Combustion Capture of Carbon Dioxide; Woodhead Publishing: Oxford, UK, 2016.

26. Ayittey, F.K.; Obek, C.A.; Saptoro, A.; Perumal, K.; Wong, M.K. Process modifications for a hot potassium carbonate-based $\mathrm{CO}_{2}$ capture system: A comparative study. Greenh. Gases Sci. Technol. 2020, 10, 130-146. [CrossRef]

27. Roine, A. HSC - Software Ver. 3.0 for Thermodynamic Calculations. In Proceedings of the International Symposium on Computer Software in Chemical and Extractive Metallurgy, Montreal, QC, Canada, 28-31 August 1989; Thompson, W.T., Ajersch, F., Eriksson, G., Eds.; Pergamon: Oxford, UK, 1989; pp. 15-29.

28. Salmón, I.R.; Cambier, N.; Luis, P. $\mathrm{CO}_{2}$ capture by alkaline solution for carbonate production: A Comparison between a packed column and a membrane contactor. Appl. Sci. 2018, 8, 996. [CrossRef]

29. Engel, D.C.; Versteeg, G.F.; van Swaaij, W.P.M. Solubility of hydrogen in aqueous solutions of sodium and potassium bicarbonate from 293 to 333 K. J. Chem. Eng. Data 1996, 41, 546-550. [CrossRef]

30. Mineralogy Database. Available online: http:/ / www.webmineral.com/ (accessed on 2 October 2017).

31. Hluchy, M.M. The value of teaching X-ray techniques and clay mineralogy to undergraduates. J. Geosci. Educ. 1999, 47, 236-240. [CrossRef]

32. Lee, Y.-H.; Kim, D.-W.; Shin, S.-I.; Oh, S.-G. Preparation of Au colloids by polyol process using $\mathrm{NaHCO}_{3}$ as a buffering agent. Mater. Chem. Phys. 2006, 100, 85-91. [CrossRef]

33. Stewart, J.A. Potassium sources, use, and potential. In Potassium in Agriculture; American Society of Agronomy (USA): Atlanta, GA, USA, 1985; pp. 83-98.

34. Smith, S.R.; Klotman, P.E.; Svetkey, L.P. Potassium chloride lowers blood pressure and causes natriuresis in older patients with hypertension. J. Am. Soc. Nephrol. 1992, 2, 1302-1309. [CrossRef] [PubMed]

35. Curlin, L.C.; Bommaraju, T.V.; Hansson, C.B. Alkali and chlorine products, chlorine and sodium hydroxide. Kirk-Othmer Encycl. Chem. Technol. 2000. [CrossRef]

36. Mahmoudkhani, M.; Keith, D.W. Low-energy sodium hydroxide recovery for $\mathrm{CO}_{2}$ capture from atmospheric airThermodynamic analysis. Int. J. Greenh. Gas Control 2009, 3, 376-384. [CrossRef]

37. McVeigh, P.; Sottocornola, M.; Foley, N.; Leahy, P.; Kiely, G. Meteorological and functional response partitioning to explain interannual variability of $\mathrm{CO}_{2}$ exchange at an Irish Atlantic blanket bog. Agric. For. Meteorol. 2014, 194, 8-19. [CrossRef]

38. Tao, L.; Tanzer, J.M.; MacAlister, T.J. Bicarbonate and potassium regulation of the shape of Streptococcus mutans NCTC 10449S. J. Bacteriol. 1987, 169, 2543-2547. [CrossRef]

39. Gómez, D.A.; Coello, J.; Maspoch, S. The influence of particle size on the intensity and reproducibility of Raman spectra of compacted samples. Vib. Spectrosc. 2019, 100, 48-56. [CrossRef] 